\title{
Human Resource Practices, Job Satisfaction and Perceived Discrimination(s) at the Workplace
}

\author{
Tullia Russo ${ }^{1}$, Tindara Addabbo ${ }^{2}$, Ylenia Curzi ${ }^{3} \&$ Barbara Pistoresi $^{4}$ \\ ${ }^{1}$ Ph.D in Labour, Development and Innovation, University of Modena and Reggio Emilia, Italy \\ ${ }^{2}$ Full Professor of Economic Policy, University of Modena and Reggio Emilia, Italy \\ ${ }^{3}$ Associate professor of Organization and Human Resource Management, University of Modena and Reggio \\ Emilia, Italy \\ ${ }^{4}$ Associate Professor of Economic Policy, University of Modena and Reggio Emilia, Italy \\ Correspondence: Tullia Russo, University of Modena and Reggio Emilia, Modena, Italy.
}

Received: June 1, 2020

Accepted: July 1, 2020

Online Published: August 20, 2020

doi:10.5539/ibr.v13n9p63

URL: https://doi.org/10.5539/ibr.v13n9p63

\begin{abstract}
This research contributes to the debate in the human resources management (HRM) literature by examining the impact of some HRM practices on workers' overall job satisfaction and the determinants of workers' perception of discrimination. The novelty of our study consists in the deepening of the relation between HRM practices and the employees' perception of discrimination in workplace: a largely unexplored topic, until now. Our aim is to add value to existing literature by assessing the synergy effect between perception of discrimination and HRM practices on workers' job satisfaction, performing a probit regression analysis of a selection of variables drawn from the sixth wave of European Working Condition Survey data, collected in 2015. We also provide a comparison of different types of discrimination, examining the moderating effect of the perception of discrimination on the relationship between HRM practices and employees' job satisfaction, assuming that the strength of the above relation is weaker for discriminated workers. Our findings highlight that HRM practices we analysed (except for autonomy of the work-group and job-intensity) have a positive impact on workers' satisfaction and reduce the perception of discrimination. Moreover, we find that the perception of every kind of discrimination have a negative impact on workers' job satisfaction. Our results also suggest that the perception of discrimination has a moderator role in the relation between HRM practices and job satisfaction. Policy implications are finally discussed.
\end{abstract}

Keywords: perceived discrimination, HRM practices, job satisfaction, workplace

\section{Introduction}

This research contributes to the debate in the human resources management (HRM) literature by examining firstly the impact of HRM practices on workers' job satisfaction and, secondly, the relation between them and the employees' perception of discrimination in workplace. Another aim is to add value to existing literature by assessing the synergy effect between perception of discrimination and HRM practices on workers' job satisfaction, through a multivariate analysis allowing to investigate the impact of a set of variables drawn from the sixth wave of European Working Condition Survey data, collected in 2015 (EWCS, 2015). We also provide a comparison of different types of discrimination, examining the moderating effect of perception of discrimination on the relationship between supportive HRM practices and job satisfaction.

Nevertheless, before going into further details, some core concepts should be clarified.

Starting from the notion of HRM practice, this element can be described as the practical implementation of organizational human resource policies: the organizational plans and procedures developed with the aim of managing people (Armstrong, 2006). Different theories have been suggested to clarify the relation between HRM practices and organizational productivity: the nucleus of these studies is provided by the literature review proposed by Jackson and Schuler (1995). Even if a review of these theories is beyond the scope of our research, we can state that the adoption of well-developed HRM practices may have an economically and statistically significant impact on levels of individual and organizational output (Hollenbeck, Noe \& Gerhart, 2018). Research highlights their positive effect on workers' motivation, attitudes and abilities (Appelbaum, 
Bailey, Berg \& Kalleberg, 2000) as well as on organizational productivity (Bartel, 1994). We will analyse in detail some specific HRM practices and their effects in the second section of this essay.

It is not possible to provide a comprehensive definition of HRM practices (and of their effects) without linking them with employees' overall perception. As a matter of fact, workers' overall perception of organizational HRM plans and procedures seems to be a crucial element in explaining workers' behaviours and attitudes (Snape \& Redman, 2010). The perception of supportive HRM practices - such as participation, training opportunity and practices to enhance discretion - contributes to the growth of workers' organizational support perception, which positively impacts the relation between the implementation of HRM practices and employees' job satisfaction (Allen, Shore \& Griffeth, 2003).

Similarly, the concept of perception of discrimination is a key factor of numerous theoretical frameworks used in economic research. It is said to exist when an employee defines its condition as discriminated when compared to the counterpart condition. Perception of discrimination may significantly affect the responses of the individual to his/her work (Hopkins, 1980) and may reduce the quality of work environment with adverse effects on employees' behaviours, relations, compliance and job related satisfaction (Colella \& King, 2018). There have been very few studies of the relation between HRM practices and workers perception of discrimination and we propose to fill this gap.

Job satisfaction is another key element of our research. Locke (1976) defined it as "a pleasure or positive emotional state resulting from the appraisal of one's job or job experiences" (p. 1304). Job satisfaction is generally determined by different variables, many of which converge into the so-called "human resources management practices" (HRMP). The past three decades have witnessed a burgeoning literature on the impact of HRMP on job satisfaction (Georgellis, Lange, Petrescu \& Simmons, 2008; R; Anuar, Ismail \& Abdin, 2014).

In 1993, Jayaratne published a wide review of literature on job satisfaction stressing that there was a little research on the impact of perceived discrimination on job satisfaction. Later in the years 2000, the impact of the perception of discrimination on job satisfaction has been increasingly analysed, in particular on the basis of age (Furunes \& Mikletun, 2010), gender (Bender, Donohue \& Heywood, 2005), disability (Uppal, 2005; Pagan, 2011 , 2013) and ethnicity (Miller \& Travers, 2005; King, Dawson, Kravitz \& Gulick, 2012). Much less literature was produced, instead, on the relation between perception of sexual orientation discrimination and job satisfaction ${ }^{1}$. Nevertheless some important research advised that heterosexual employees generally experienced higher levels of job satisfaction than gay and lesbian workers (Sears \& Mallory, 2011; Badgett \& Frank, 2007) and that this may be due to the high levels of workplace violence and harassment experienced by LGB people as well as to the inequality in wages, career opportunities and job responsibilities (Drydakis, 2015).

With all this considered, it is crucial for organizational management to understand employees' perceptions of discrimination at work, because these perceptions can affect their behaviour, their relations, their attitudes and, consequently, the economic health of the company.

The paper is structured as follows. In the next section we present our theoretical background and framework. In particular, we firstly show the HRM practices used in our probit models, which may impact on the workers' perception of discrimination and on their overall job-related satisfaction. Secondly, we present the available literature on the relation between perception of discrimination and work satisfaction. A description of our methodology, data analysis and techniques is followed by a section showing the findings of our analysis and then a discussion session. Our findings highlight that, in our sample of the 6th EWC survey, some HRM practices have a direct effect on perception of discrimination and that perception of each kind of discrimination, as well as an intersectional discrimination, negatively impact job satisfaction. The paper ends with our conclusions and implications.

\section{HRM Practices, Job characteristics, Perceived Discrimination and Job Satisfaction: A Theoretical Background}

The method to managing diversity is a HRM practice that affects the organizational effectiveness, the individual behaviours and feelings and the relations between management and employees, as well as the relations between co-workers (Ensher, Grant-Vallone \& Donaldson, 2001).

A primary purpose of this study is to show empirical evidence for the impact of HRM practices on employees' job satisfaction. We will also analyse the impact of different job characteristics on individual and work related

\footnotetext{
${ }^{1}$ Studies on the impact of workers perception of transphobia on their job satisfaction are even rarer than those on perception of sexual orientation discrimination.
} 
outcomes, comprising job satisfaction. A secondary aim of our research is to explore HRM practices potential role on workers' perception of discrimination, on the ground of five different characteristics: sexual orientation, age, disability, gender and ethnicity.

We started the analysis from the assumption that a growing body of research has found by over the past decades a positive relation between inclusive HRM practices and organizational performance (Zacharatos, Barling, \& Iverson, 2005). Most studies, indeed, underlined that well-developed HRM practices may lead to desirable employee states and behaviours and, consequently, to high organizational outcomes. Kopelman, Brief and Guzzo (1990) have been pioneers in the analysis of the role of the environment work (organizational culture and climate) on workers' cognitive and affective status (work motivation and job satisfaction), on salient organizational behaviours (attachment, performance, perceptions, citizenship, feeling) and, consequently, on work effectiveness (organizational productivity). Starting from these theories, Ostroff and Bowen (2000) developed a theoretical model examining the linkage between HRM practices, the perception that workers have of them and employees' performances, adopting the organizational climate as a mediator of the relation between HRM practices and workers' performances. Considering that climate is referred to as the perception of these official and non-official organizational policies, strategies and measures, it follows that the HRM practices can play a crucial role in defining workers' perceptions of the organizational climate.

In the light of the theories just mentioned and because an organizational climate can be perceived as discriminatory and exclusionary or, on the contrary, as inclusive and free of discrimination, we can generally expect that inclusive HRM practices will reduce workers' perception of discrimination.

In the next sections we analyse, one by one, the HRM practices used in our models in order to provide a theoretical basis for the findings concerning each of them. Considering that the policies and measures adopted by an organization should be determined by the strategic aims and ideals of the organization (Ostroff \& Bowen, 2000), the set of practices we selected as predictors of job satisfaction and perception of discrimination refer to an HRM system ideally and firstly aimed to employees' inclusion ${ }^{2}$ but also some practices that may have a not-obvious effect.

\subsection{Autonomy \& Discretion}

Job autonomy is recognized as one of the most important resources positively affecting both employees' attitudes towards work as well as organizational performance (Shaufeli and Taris, 2014).

In the literature job-autonomy is analysed as a synonym of job-discretion: the authority to exercise valuation and make decisions without interferences, or with minimal interferences, as well as the freedom to define the practical, physical and temporal limits of work (Engel, 1970; Wallace, 1995).

In the light of these considerations, it is generally assumed that employees who experience less discretion and autonomy on how to conduct their work, or how to solve problems on their own, result consequently more dissatisfied with work than their counterpart endowed with discretion and autonomy, particularly in specialized work. As a matter of fact, workers who are equipped with specialized tools feel more frustrated in front of the impossibility to act and make discretionally or autonomous decisions than unskilled workers (Pilati \& Innocenti, 2008; Bartling, Fehr \& Schmidt, 2013).

Reduction or limitation of workers' discretionary and autonomous powers can be perceived as a discriminatory act by those employees who belong to minorities (Lait \& Wallace, 2002). Therefore, it is reasonable to assume that discretion and autonomy are negatively correlated with employees' perception of discrimination and with their job-satisfaction in the workplace.

Furthermore, autonomy effects are not as simple and linear as they might seem. Extensive literature exists on the Paradox of Autonomy, particularly evident in self-managing teams, where autonomy frequently ends up increasing control over individual members (Albano et al., 2018), as well as in some specific professions and jobs (Alvesson and Robertson, 2006; Robertson, Scarbrough \& Swan, 2003).

It may be difficult to understand the difference between the concepts of discretion and autonomy. To the best of our knowledge, it is necessary to distinguish between these notions in the work regulation. Maggi (2016) defines discretion as the workers ability to decide how to act, across a range of pre-established alternative procedures, on the strength of previous guidelines. The concept of autonomy is, instead, related to the capability to produce

\footnotetext{
2 Diverse amount and forms of the practices selected have been found to impact on organizational productivity, in different ways. An important meta-analysis of the effects of intervention programs on worker productivity is provided by Guzzo, Jette and Katzell (1985).
} 
one's own rules and manage one's own process of action and decisions (Maggi, 2016). Thus, the difference is subtle but relevant and Section 4, dedicated to variables and measures, will provide an operationalization of these concepts.

\subsection{Team Endowed with Discretion}

Some scholars have found that increased discretion may also rise monitoring and control over workers, with the effect of reducing employees' motivation and satisfaction (Stewart \& Barrik, 2000; Albano et al.2018). Discretion can, indeed, generate a paradox, which reflects the trade-off between workers' interest in personal discretion and the possible highest level of control and judgment acted by colleagues, clients or management. We will identify this as the Discretion Paradox.

Barker (1999) found that this paradox is more frequent in self-managing teams rather than in individual workers which work independently: the job satisfaction of team members is determined by several factors such as the composition of the group and the relations between members, the characteristics of the work itself, the intragroup rules, the supervisors' control. All these aspects act in combination and that is why the relation through which teamwork influences job satisfaction is neither simple nor linear (Griffin, Patterson \& West, 2001).

Analysing autonomy and discretion of a team as determinants of perception of discrimination, we can argue that individual autonomy and discretion can be generally expected as factors that will decrease negative feelings and emotions, but the expectations change taking into account the autonomy and the discretion of a group-work. More specifically, a group can be inclusive and non-discriminatory (e.g. cohesive ${ }^{3}$ ) or not. The social identity theory suggests that a cohesive work group needs no intra-group hostile relations as well as members' identification with the in-group (Tajfel, Turner, Austin \& Worchel, 1979). Even though work group identification has been found to be linked to work group satisfaction, different studies have also shown that it is often a trigger for intergroup conflicts and discrimination: with the aim of reducing insecurity and improve their self-esteem, work group members may try to increase their group's power through an intergroup discrimination and a strong subgroup alliance (Hogg \& Terry, 2000).

We can expect that while individual autonomy and discretion are positively correlated with workers' overall job-satisfaction and negatively with the perception of discrimination, the expected result for the autonomy and the discretion of a work group is the exact opposite.

\subsection{Job-intensity}

Work intensity is both a physical and a psychological issue. It can be described as "conditions having long difficult working hours, pressure to work overtime, lesser holidays or breaks, unreasonable work overload, and improbable expectations of what can be achieved in some given limited time and with available resources" (Altaf \& Awan, 2011, p. 93). Literature shows that work overload, time pressure, tight deadlines and high-speed work directly contribute to decrease psychophysical well-being and, consequently, to reduce job-related satisfaction (Zeytinoglu Denton, Davies, Baumann, Blythe \& Boos, 2007; Silla \& Gamero, 2010). Some scholars found that the introduction of job-intensity schemes can be perceived by workers as bullying and discriminatory acts, impacting negatively on stress and well-being (Lait \& Wallace, 2002). With these premises, a negative relation between job-intensity and job-satisfaction is expected. Moreover, we predict that an employee under work-related pressure may report higher levels of perceived discrimination than an employee without tight pace of work.

\subsection{Performance-related Pay}

The adoption of a performance pay system has been found to intensify employees' efficiency, effort and wages (Armstrong and Baron, 2005). Nevertheless, the effects of these pay schemes on workers job-related satisfaction is not automatically positive. Higher wages increase employee satisfaction, but other dimensions of pay systems based on performance may have an adverse impact on overall work satisfaction. Performance-related pay can, indeed, lead to uncertain earnings, increased efforts, earning dispersion and, consequently, may reduce employee satisfaction (Green \& Heywood, 2007). Moreover, Marsden and French (1998) highlighted that individual performance pay scheme can divide workforce, reduce employees' disposition to collaborate with management and lead management to attribute lower scores to keep from paying. In the light of these considerations, this type of performance appraisal may be expected to increase perception of discrimination and reduce workers' overall job satisfaction.

\footnotetext{
${ }^{3}$ Langfred (2000) defined group cohesiveness as "the extent to which group members like, and interact with,
} other group members and want to remain part of the group" (p. 567). 


\subsection{Job Training}

Landy (1985) talked about job training as "a set of planned activities on the part of an organization to increase the job knowledge and skills or to modify the attitudes and social behaviour of its members in ways consistent with the goals of the organization and the requirements of the job" (p. 306). Some scholars do not consider job training as an element of job satisfaction: for instance, Koustelios and Bagiatis' analysis (1997) gauged overall work satisfaction through a six-factor scale including the presence of an immediate supervisor, pay schemes, working conditions, the job itself, the organization, and prospects for promotion. Moreover, Schwepker's study (2001) measured job satisfaction using the following constructs: promotion and advancement, pay schemes, supervisors, organizational policy and support, customers, co-workers and job characteristics. Finally, also Shapiro, Burkey, Dorman, and Welker's research (1996) evaluated job satisfaction adopting a six-factor scale without involving job training but considering futility/avoidance, self-actualization, job-related affect, support, self-esteem and working conditions.

We decided to introduce job training in our model regarding the determinants of overall job satisfaction because it can, however, be considered as a dimension of 'internal service quality' in the working environment, and that is why it can contribute greatly to workers' overall job-related satisfaction (Burke, 1995; Heskett et al., 1994). As a matter of fact, a wide literature, available from different disciplines, has found a positive relation between job training and employees' satisfaction (Conrade \& Woods, 1994; Hanaysha, Tahir, 2015). Furthermore, a well-developed job training programme can have a crucial impact on workers' perception of discrimination. Cox and Blake (1991) suggested the introduction of two types of training: awareness training, addressed to management, in order to create an understanding on diversity related issues, and a skill-building training aimed to educate workforce on differences and, consequently, to create a more anti-discriminatory climate. In the light of this, a positive impact of job-training on minority workers' perception of discrimination can reasonably be expected.

\subsection{Support}

The individual support cannot be considered as a concrete traditional HRM practice. Anyway, we decided to use this element in our analysis because of its nature: it can be, indeed, a consequence of a casual set of factors, such as empathy or friendship, but also the result of a specific inclusive-oriented organizational policy.

In our analysis, we distinguish the role of the supervisors' support and the role of colleagues' support in determining workers' job satisfaction, as suggested by French, Rogers and Cobb (1974).

Kim, Lee and Sung (2013) noted that workers' perception of supervisors' support had a moderating role in the impact of HRM inclusive practices and the perception of gender discrimination on workers' job satisfaction: more specifically, they found that the interaction between supportive HRM practices and boss' support can increase workers' job satisfaction to a much higher standard and that the negative effect of perception of discrimination on job satisfaction can be moderated by supervisors' support.

Supervisors play a decisive role in defining the structure and the nature of the work environment, sharing knowledge, goals and information, providing feedback, asking for opinions. Their decisions have a concrete impact on employees' behaviours and commitment as well as on work-related satisfaction of workers (Durham, Knight \& Locke, 1997). On the other side, colleagues' support is crucial in increasing a feeling of belongingness to the company (or eventually to the work-group) that impacts, consequently, on job satisfaction (Ducharme, Martin, 2000; Abraham, 2012), as well as on perception of discrimination (Storey \& Garff, 1997; Chou \& Choi, 2011).

In light of this, a positive impact of co-workers and supervisors' support on minority workers' perception of discrimination can reasonably be expected.

\section{The Relation between the Perception of Discrimination and Workers' Job Satisfaction: A Theoretical Background}

The increasing differences among employees in terms of age, gender, cultural and social background, physical abilities, ethnicity, sexual orientation, gender identity, religion (and others) present several new challenges and opportunities from the perspective of management. Employing heterogeneous workforce grants different advantages for the organization, such as an increased presence of high-performance employees, a stronger productivity growth, more creativity and innovation, and others (Cox \& Blake, 1991). However, in a work-environment of different individuals, some minority workers can consider their condition as discriminated when compared to the others condition, because of one (or more) specific characteristic. Additionally, since employees' belief affects their satisfaction, relations, compliances, performances, and attitudes, whether or not 
they are real (Gibson \& Teasley, 1973), employers have to pay attention to their perceptions and feelings. Therefore, to guarantee the achievement of the benefits over mentioned, organizations need to implement ad hoc inclusion policies and specific HRM practices in response to their minority workers' sense of marginalization and exclusion.

Past studies have investigated the consequences of employees' perceived discrimination (on the ground of age, ethnicity, disability, gender and sexual orientation) and its effect on their work-related attitudes and behaviours. In this section we expose some of the most important studies on the effect of the perception (of different types) of discrimination on workers' job satisfaction, in order to provide a theoretical basis for our findings, dividing them by the characteristic subject of discrimination.

\subsection{Perception of Age-Discrimination}

Research on age-discrimination and older workers has been increasing for over thirty years because of the changing demographic of the labour force, which also concerns individual expertise and skills (Doubbelaere \& Goeppinger, 1991). An important study on issues involving consequences of age-discrimination in workplace found that older employees' perception of discrimination was negatively related to self-esteem and overall work satisfaction (Hassel, Parrewè, 1993). More recently, Taylor, McLoughling, Meyer and Brooke (2013) have analysed a worker survey data collected within Australian organisations, realizing a statistically reliable model of the direct effect of everyday age-based discrimination on psychological wellbeing and job satisfaction. The survey was carried out in two phases (2007 and 2008) and in diverse environments: two international terminals of an airline, a public university, a factory and in the roadside assistance of a car company. Psycho-social factors, such as job insecurity, were included using a structural equation modelling.

Their findings highlighted that age-related everyday discrimination negatively impacts on job satisfaction, consistently with literature.

\subsection{Perception of Discrimination Based on Ethnicity}

Ensher, Grant-Vallone and Donaldson (2001) explored the perception of discrimination of 366 ethnically diverse workers from a wide variety of work environments and professional categories, analysing data collected for the project Workwell in Los Angeles, California. To measure their job satisfaction, there were used five items from the Job Content Questionnaire (Karasek, 1985). This measure included the item "How satisfied are you with your job?" which was found to have high internal consistency (alpha 5.81). The authors observed how workers' perceptions of ethnical discrimination impacted on their job-related satisfaction, organizational commitment, grievances and organizational citizenship behaviour, found that multiple levels perceived discrimination affected all the considered dimensions, except for grievances ${ }^{4}$.

Another important research on ethnicity discrimination as a determinant of job satisfaction is the study of Sanchez and Brock (1996). They analysed the consequences of perceived ethnical discrimination on work performances and attitudes. The target population employed was Hispanics resident in Dade County, Florida: a county where 44 percent of the population was Hispanic. In their study, the perception of discrimination was gauged with 10 items and it analysed data through a regression analysis. Sanchez and Brock (1996) results showed that workers' perception of ethnical discrimination adversely impacted on overall job satisfaction much more than other general work-related stressors, such as fighting with colleagues or supervisors and job uncertainty. They also found that employees with higher levels of education and wages perceived less discrimination than others.

This last finding is in contrast with the so-called Paradox of Integration (Buijs, Demant \& Hamdy, 2006; Entzinger, Dourleijn, 2008; Verkuyuten, 2016) which suggests, on the contrary, that people declaring to have a high level of education or of wage should be expected to report more perceived discrimination. Following this theory, we can assume that more educated people are more likely to know their rights and feel comfortable reporting to have perceived discrimination, than those with the lowest level of education (Cardarelli, Cardarelli \& Luz Chiapa, 2007; Verkuyuten, 2016).

\subsection{Perception of Discrimination Based on Disability}

Considering disability-based discrimination, a significant study (Goodyear \& Stude, 1975) compared the job performance of 21 employees with a severe disability and that of 22 nondisabled workers, underlining that the

\footnotetext{
${ }^{4}$ In contrast to Ensher, Grant-Vallone and Donaldson thesis (2001), Allen and Keaveny (1985) found that employees perceiving an unfair treatment are more likely to file grievances than those who believe they are being treated fairly.
} 
first ones reported higher level of job satisfaction than the others, because their work-opportunities were lower and, so, their job gave them a greater satisfaction. More recent studies have found a similar result (Akkerman, Kef \& Meininger, 2018; Kocman \& Weber, 2018), suggesting that when disabled workers are needed job-related supports and given the chance, they are able to work as adequately as nondisabled employees and, consequently, absolutely satisfied with work. Nevertheless, if workers with disability are generally and moderately more satisfied than those without but they happen to experience more discrimination, they can report similar (or lower) levels of job satisfaction to those of workers without disability (Stone \& Colella, 1996; Perry, Hendricks \& Broadbent, 2000). It should be added that diverse types of disabilities are exposed to diverse levels of discrimination (Uppal, 2005).

\subsection{Perception of Gender-Discrimination}

A wide literature on gender discrimination and its consequences on discriminated workers is today available. Several studies, for a long time now, have shown that the so-called women segregation and the gender-pay gap impact negatively on women's overall job satisfaction and on their stress (Albert, Escot \& Fernández-Cornejo, 2011; Nadler, Voyles, Cocke \& Lowery, 2016). Women who report to perceive gender-based discrimination and to experience harassment at work may also suffer physical and psychological effects (Branscombe, Kobrynowicz \& Owen, 2002; Aman, Asif, Qazi \& Aziz, 2016). Also the so-called glass ceiling and the sticky-floor phenomena have found to impact negatively on job satisfaction (Duraysami \& Duraysami, 2016) as well as on commitment and enthusiasm (Channar, Abbassi \& Ujan, 2011).

\subsection{Perception of Discrimination Based on Sexual Orientation}

LGB (lesbian, gay and bisexual) workers constitute one of the least analysed and studied minority groups in the labour force. The last extensive and systematic literature review on sexual orientation discrimination in job environments is not very recent and dates back to 2014 (Ozeren, 2014).

In the last years, the interest in this topic has grown and several studies have been conducted to explore this kind of discrimination (and its consequences) in workplace, also because today LGB persons are considered "a fairly large minority group to have important implications for labour and consumer markets" (Day \& Greene, 2008, p.639).

With regard to job satisfaction, Carpenter (2005) analysed the 2003 Canadian Community Health Survey, restricted to a subsample of individuals living in three Canadian regions (Ontario, Newfoundland, and Saskatchewan), showing evidence of differences in job satisfaction among individual reporting different sexual orientations. Gay and lesbians workers reported statistically significant higher level of job satisfaction than heterosexual individuals. Moreover, Hammarstedt, Aldén, and Swahnberg (2018-2020) found that homophobic discrimination may lead homosexual workers to have low expectations about their job and, consequently, to report a higher job satisfaction than their heterosexual counterpart.

Research also demonstrates that LGB employees suffer of different form of sexual orientation-based discrimination in workplace, starting from discrimination in hiring (Patacchini, Ragusa, Zenou, 2015), proceeding with pecuniary discrimination (Badgett, Lau, Sears \& Ho 2007; Drydakis, 2012-2015; Ahmed, Andersson \& Hammarstedt, 2012) and everyday harassment (European Union Agency for Fundamental Rights report, 2009), to end with institutionalised discrimination (Badgett et al. 2007). Since abuse, perceived discrimination, discriminatory payments and advancements are suggested to decrease job satisfaction (Leppel \& Clain, 2015), we can expect that LGB workers who perceived discrimination are very likely to report less job satisfaction than employees who do not.

\subsection{Perception of Discrimination Based on More Than One Characteristic (Intersectionality)}

Our research also contributes to the debate in the HRM literature by examining the role of intersectionality on workers attitudes. The concept of intersectionality was coined in 1989 to highlight the heaviest consequences of intersection of ethnicity and sex discrimination on individuals (Crenshaw, 1989). Today, this concept arises out of feminist subject to describe the phenomenon of different forms of discrimination related one to another, and its consequences. We analyse the effects of a possible interaction among the perception of discrimination on the ground of sexual orientation with the characteristics of biological sex, race, religion, nationality and disability in workplaces. Research on intersectionality in the workplace reveals that employee with multiple memberships in minorities classes experience more discrimination than those with a single membership (Buchanan et al. 2009; Purdie-Vaughns \& Eibach, 2008). As a consequence, employees intersectionally discriminated are found to have a more negative work attitude (European Industrial Relations Observatory, 2000), less job satisfaction and less wellness as compared to their counterpart (Taylor et al. 2013). 


\section{Hypothesis}

In the light of the arguments presented in the two previous sections, we hypothesize that:

HRM practices affect both job satisfaction and workers' perception of discrimination. Specifically, we hypothesize the following:

Hypothesis 1. HRM practices (stated in Section 1) have a positive influence on employees' job satisfaction, while as far as the job characteristics are concerned a negative effect on job satisfaction can be expected by work group's discretion, because of the discretion paradox, and by job intensity.

Hypothesis 2. HRM supportive practices decrease workers' perception of any kind of discrimination, except for HRM that produce higher work group's discretion, because of the discretion paradox, enhance job intensity and introduce pay for performance schemes.

Hypothesis 3. Perception of discrimination is negatively associated with workers' job satisfaction.

Taken together, these three first hypotheses specify both a direct and an indirect effect of HRM practices and their outcomes in terms of job characteristics on employees' job satisfaction.

Finally, the present study examines the potential role of perceived discrimination as a moderator of the influence of HRM practices on workers' overall job-related satisfaction.

Hypothesis 4. Perception of discrimination moderates the relationship between inclusive HRM practice and job satisfaction.

\section{Methods}

\subsection{Data Source and Sample}

The data set used to carry out the analysis is the 6th European Working Conditions Survey (EWCS). This survey has been chosen since it provides data comparable across countries on working conditions and on indicators of HRM practices outcomes. Additional information that is highly relevant for this study concerns the perception of different types of discrimination as well as individual job satisfaction.

EWCS does not contain questions neither on individuals' sexual orientation nor on their gender identity 5 . However, linking the answers related to the members of the household with those on the type of relationship between them and the respondent, we have achieved a subsample of women declaring to have a woman spouse or cohabitee and of men declaring to have a man spouse or cohabitee. The former represents $0.6 \%$ of the entire sample while the latter the $1 \%$. We decided to not use this subsample in our analysis because it is not representative of the LGB population of the sample: people who declare to have a same-sex partner do not correspond to the whole LGB sub-sample of our data set.

The target population is composed by all individuals aged 15 years and over (16 and over in Bulgaria, Norway, Spain and the UK) who were in employment and resident in one of the 35 countries surveyed. In each of them, a multi-stage, stratified clustered sampling design was adopted. A total of approximately 44,000 workers took part in the survey. The respondent's demographics were 50.4 percent male and the majority of the respondents were between 36 and 55 years old (53\%). In addition almost one third (32.6\%) declared to have a high level of education.

Relating to HRM practices outcomes, more than 5 thousands respondents (11.5\%) are equipped with individual autonomy in their current job, while more than half stated to work in autonomous workgroups (52.6\%). Almost one third (31\%) is, instead, endowed with discretion. Nearly 13,000 respondents (29.5\%) declared to currently perceive the support of their own supervisors, while approximately 18,800 (42.8\%) the support of their colleagues. Moreover, around a quarter of respondents (24.2\%) are under performance-pay schemes while 7.3\% declared to work at tight and intense pace of work. Considering on the job training, $42 \%$ of the sample stated to receive it. Finally, $16.8 \%$ stated to feel satisfied with their work, $52 \%$ of which are males.

Considering discriminated workers, more than 3.000 people (7\%) reported discrimination perceived over the past 12 months in the workplace, on the ground of sexual orientation $(0.5 \%)$, age $(3.3 \%)$, gender $(2 \%)$, disability $(1 \%)$, ethnicity $(1.6 \%)$, religion $(0.9 \%)$ or nationality $(1.8 \%)$, while 581 workers $(1.3 \%)$ declared to have perceived intersectional discrimination. Moreover, most of them (85\%) are employees and $22 \%$ stated to do part-time work. More than half $(62.3 \%)$ declared to be engaged under an open-ended contract and a similar

${ }^{5}$ In order to better understand the concepts of sexual orientation and gender identity, see: Russo and Valerio (2019). 
percentage $(64.8 \%)$ work in private sector, against $24.8 \%$ in public sector, $5 \%$ in joint private-public organizations or companies, $1.5 \%$ in the not-for-profit sector or NGO and the rest $(2.8 \%)$ in other sectors.

\subsection{Variables and Measures}

This section shows the main EWCS (2015) items used in the empirical analysis presented in the next section. All variables used in our models have a dichotomous (zero-one) distribution, except for Age. The complete list of them, their meaning and labels can be found in Appendix (Table 1).

\subsubsection{Job Satisfaction}

Job Satisfaction is the dependent variable of Models presented in Table 1. Information about participants' job satisfaction was captured from these five EWCS (2015) questions:

[Q70d] Do you agree with the statement "The work is distributed fairly"?

[Q89a] Do you agree with the statement "Considering all my efforts and achievements in my job, I feel I get paid appropriately"?

[Q89b] Do you agree with the statement "My job offers good prospects for career advancement"?

[Q89c] Do you agree with the statement "I receive the recognition I deserve for my work"?

These items were answered on a five point scale ranging from 1="Strongly Agree" to 5="Strongly disagree".

Another specific item was taken into consideration:

[Q88] On the whole, are you very satisfied, satisfied, not very satisfied or not at all satisfied with working conditions in you main job paid?

This last item was answered on a four point scale ranging from 1= "Very satisfied" to 4= "Not at all satisfied".

Each item has been dichotomised, defining five new dummy variables. These take the value 1 when the answers to questions are $=1$ or $=2$, and vice versa. The aggregation of those five indicators provided the summary Job Satisfaction dichotomous variable of our analysis. More specifically, at Job Satisfaction=1 a worker is considered satisfied, when at least 3 out of 5 answers are $=1$. At Job Satisfaction=0 a worker is considered not satisfied.

\subsubsection{HRM Practices}

The eight HRM practices/practices outcomes used in our analysis were measured using dichotomous indicators ( $1=$ the practice has been implemented; $0=$ otherwise). Unless indicated otherwise, all the variables have been dichotomised with the procedure implemented for Job Satisfaction variable.

The following list describes them one by one, showing the items with which they have been developed.

\section{Autonomy.}

Autonomy was assessed by five items, based on the study of Albano et al. (2018) and of the correlation matrix showing the extent of the similarity between job satisfaction and some specific autonomy-oriented HRM practices (see Table 2 in Appendix):

[Q53f] Generally, does your main paid job involve learning new things?

[Q61c] Are you consulted before objectives are set for your work?

[Q61d] Are you involved in improving the work organisation or work process of your department or organisation?

[Q61e] Do you have a say in the choice of your work colleagues?

[Q61i] Are you able to apply your own ideas in your work?

\section{Discretion.}

Discretion was measured by five items selected, they too, on the basis of the theory exposed in Section 1 (Maggi, 2003/2016) and of the correlation matrix showing the extent of the similarity between job satisfaction and some specific discretion-oriented HRM practices (see Table 3 in Appendix). The items are the following:

[Q53b] Generally, does your main paid job involve assessing yourself the quality of your own work?

[Q53c] Generally, does your main paid job involve solving unforeseen problems on your own?

[Q53e] Generally, does your main paid job involve complex tasks?

[Q54a] Are you able to choose or change your order of tasks? 
[Q54b] Are you able to choose or change your methods of work?

Discretion of the team.

This variable was designed by only one item:

[Q88] Do you work in a group or team that has common tasks and can plan its work?

Intensity.

Intensity was assessed by twelve items, selected in order to take into account every single aspects of this measure which can negatively impacts on workers' overall job satisfaction. The items involved are the following:

Items on high speed and tight deadlines:

[Q49a] Does your job involve working at very high speed?

[Q49b] Does your job involve working to tight deadlines?

[Q61g] Do you have enough time to get the job done?

Items on work pressure: "On the whole, is your pace of work dependent on..."

[Q50a] the work done by colleagues;

[Q50b] direct demands from people such as customers, passengers, pupils, patients, etc.;

[Q50c] numerical production targets of performance targets;

[Q50d] automatic speed of a machine or movement of a product;

[Q50e] the direct control of your boss.

Item on disruptive interruptions:

[Q51] How often do you have to interrupt a task you are doing in order to take on an unforeseen task?

Items on working hours and recovery time:

[Q37d] Normally, how many times a month do you work more than 10 hours a day?

[Q38] In the last month, has it happened at least once that you had less than 11 hours between the end of your working day and the start of the next working day?

[Q46] How often have you worked in your free time to meet work demands?

\section{Pay for Performance.}

The measure of performance pay was developed based on the following five items:

"Thinking about your earnings from your main paid job, what they include?"

[Q101b] Piece rate of productivity payments;

[Q101f] Payments based on your individual performance;

[Q101g] Payments based on the performance of your team / working group / department;

[Q101h] Payments based on the overall performance of the company (profit share scheme) where you work;

[Q101i] Income from shares in the company you work for.

\section{Training.}

Training is assessed by two items which involve a specific professional growth-oriented choice made by the company:

[Q65a] Have you undergone training paid for or provided by your employer, to improve your skills?

[Q65c] Have you undergone on-the-job-training (co-workers, supervisors), to improve your skills?

Support of the boss.

The variable related to the support received by the supervisor is defined by the following seven items:

[Q61b] Does your manager help and support you?

[Q63a] Does your immediate boss respect you as a person?

[Q63b] Does your immediate boss give you praise and recognition when you do a good job?

[Q63c] Is your immediate boss successful in getting people to work together? 
[Q63d] Is your immediate boss helpful in getting the job done?

[Q63e] Does your immediate boss provide useful feedback on your work?

[Q63f] Does your immediate boss encourage and support your development?

\section{Support of colleagues.}

The last variable related to HRM practices is measured by three items:

[Q61a] Do your colleagues help and support you?

[Q70e] Is there a good cooperation between you and your colleagues?

[Q89d] Do you generally get on well with your work colleagues?

\subsubsection{Perception of Discrimination}

Perception of discrimination is the dependent variable of models exposed in Table 2. The European Working Condition Survey (EWCS, 2015) attempts to capture workers perception about the discrimination suffered - on the ground of sexual orientation, gender, ethnicity, disability or age - asking just one question [Q72]: "Over the past 12 months at work, have you been subjected to any of the following discriminations [...]".

Respondents have only two possible answers: "yes" or "not". In details, with sexual orientation-gender-age-disability-ethnicity discrimination $=1$ a worker is deemed discriminated and vice-versa.

For the purpose of our analysis, we created also two additional dichotomous variables: Discrimination and Intersectionality with Sexual Orientation Discrimination. The firs one is $=1$ when a worker declared to perceive at least one of the five possible discrimination and it is $=0$ when the respondent does not perceive any kind of discrimination. The second one is $=1$ when an employee perceive discrimination on the ground of sexual orientation and at least another kind of discrimination, and vice versa.

\subsection{Control Variables}

In our models a set of control variables have been included on the ground of their expected effect on job satisfaction. These are presented in Appendix. Amongst them, Rule of Law Countries is of particularly importance: it is a dichotomous variable $=1$ if the respondent works in one of the five countries on the top list of countries where the rule of law is better experienced by the general public (WJP Rule of Law, 2015). It is reasonably expected that workers living in these regions will experience less discrimination in the workplace. The top five countries are Denmark, Norway, Sweden, Finland and Netherlands. Another relevant control variable is Trust the Management: it is a dichotomous variable $=1$ if respondents strongly agree or agree with the statement [Q70f] "In general, employees trust management" and $=0$ if they neither agree nor disagree, tend to disagree or strongly disagree. We decided to take into account this item because of its role as moderator in the relationship between HRM practices and employees' attitudes, analysed by Innocenti, Pilati and Peluso (2011).

\section{Results}

\subsection{Data Analysis}

EWCS (2015) data were analysed in four different phases. Firstly we estimated a probit model (Table 1) in order to verify which set of HRM practices or job characteristic was most likely to have a positive impact on employees' overall job satisfaction (Hypothesis 1). We also tested if the perception of discrimination increases the probability of reporting lower level of job satisfaction (Hypothesis 3). Control variables were included.

Secondly, we examined which set of HRM practices was most likely to affect workers' perception of discrimination (Table 2). We tested the probability of perceiving discrimination in general, intersectionally starting from sexual orientation discrimination and, separately, on the ground of sexual orientation, age, disability, ethnicity and gender. All the control variables (see Appendix) were included in this first model. Probit analysis was used to test the Hypothesis 3 .

Finally, interaction terms between HRM practices and discrimination were developed and used to test the likelihood that the improving effect of HRM practices on job satisfaction should be less pronounced when linked with the perception of discrimination (Hypothesis 4). Probit analysis was used to test our last hypothesis, and all performed models were included in Table 3.

\subsection{Statistics and Results}

Observing Model 1 in Table 1, a positive relation between some HRM practices outcomes and employees' overall job-related satisfaction can be note. In details: autonomy, colleagues and supervisors'support, discretion, pay for performances schemes and job training are HRM practices that all have a positive impact on workers' 
satisfaction. Consistent with literature (Green and Tsitsianis, 2005; Zeytinoglu et al., 2007; Silla \& Gamero, 2010), we also find that work in team endowed with discretion and job intensity can increase the probability of reporting less satisfaction compared to employees who work alone and without fast pace. This finding supports the Hypothesis 1.

Observing and comparing models 2-8 (Table 1), each of which is related to a specific discrimination, we find that perception of every kind of discrimination increases the chance of reporting less job-satisfaction, supporting the Hypothesis 3.

Also detecting control variables we find significant information about workers' job satisfaction. Our analysis shows that females, individual with lower level of education, older workers and self-employed people are more likely to report less job satisfaction than their counterparts. Results also showed that workers who live in one of the five "rule of law" countries have a higher chance of being satisfied with their job (p-value<0.01), as well as workers declaring to trust management ( $\mathrm{p}$-value $<0.01$ ).

Table 1. Probit estimation of the effect of HRM practices and perception of different types of discrimination on job satisfaction. Dependent variable: workers' job satisfaction that takes the value of 1 if the worker is satisfied by their work. Marginal effects, 2015

\begin{tabular}{|c|c|c|c|c|c|c|c|c|}
\hline VARIABLES & Model 1 & Model 2 & Model 3 & Model 4 & Model 5 & Model 6 & Model 7 & Model 8 \\
\hline autonomy & $\begin{array}{l}0.0897 * * * \\
(0.00595)\end{array}$ & $\begin{array}{l}0.0892 * * * \\
(0.00594)\end{array}$ & $\begin{array}{l}0.0902 * * * \\
(0.00598)\end{array}$ & $\begin{array}{l}0.0893 * * * \\
(0.00594)\end{array}$ & $\begin{array}{l}0.0900 \text { *** } \\
(0.00597)\end{array}$ & $\begin{array}{l}0.0899 * * * \\
(0.00597)\end{array}$ & $\begin{array}{l}0.0904 * * * \\
(0.00598)\end{array}$ & $\begin{array}{l}0.0898 * * * \\
(0.00596)\end{array}$ \\
\hline discretion of the team & $\begin{array}{l}-0.00662 * * \\
(0.00286)\end{array}$ & $\begin{array}{l}-0.00618 * * \\
(0.00285)\end{array}$ & $\begin{array}{l}-0.00684 * * \\
(0.00288)\end{array}$ & $\begin{array}{l}-0.00636 * * \\
(0.00286)\end{array}$ & $\begin{array}{l}-0.00677 * * \\
(0.00288)\end{array}$ & $\begin{array}{l}-0.00637 * * \\
(0.00287)\end{array}$ & $\begin{array}{l}-0.00643 * * \\
(0.00288)\end{array}$ & $\begin{array}{l}-0.00660^{* * *} \\
(0.00287)\end{array}$ \\
\hline colleagues support & $\begin{array}{l}0.0802 * * * \\
(0.00362)\end{array}$ & $\begin{array}{l}0.0779 * * * \\
(0.00359)\end{array}$ & $\begin{array}{l}0.0800 * * * \\
(0.00363)\end{array}$ & $\begin{array}{l}0.0791 * * * \\
(0.00361)\end{array}$ & $\begin{array}{l}0.0796^{* * * *} \\
(0.00362)\end{array}$ & $\begin{array}{l}0.0790 * * * \\
(0.00361)\end{array}$ & $\begin{array}{l}0.0796 * * * * \\
(0.00362)\end{array}$ & $\begin{array}{l}0.0800 * * * * \\
(0.00362)\end{array}$ \\
\hline boss support & $\begin{array}{l}0.0989^{* * * *} \\
(0.00412)\end{array}$ & $\begin{array}{l}0.0972^{* * * *} \\
(0.00410)\end{array}$ & $\begin{array}{l}0.0996^{* * * *} \\
(0.00414)\end{array}$ & $\begin{array}{l}0.0981 * * * * \\
(0.00411)\end{array}$ & $\begin{array}{l}0.0997 * * * \\
(0.00414)\end{array}$ & $\begin{array}{l}0.0990^{* * * *} \\
(0.00413)\end{array}$ & $\begin{array}{l}0.0994 * * * * \\
(0.00414)\end{array}$ & $\begin{array}{l}0.0990 * * * \\
(0.00413)\end{array}$ \\
\hline intensity & $\begin{array}{l}-0.0390 * * * * \\
(0.00420)\end{array}$ & $\begin{array}{l}-0.0375 * * * \\
(0.00424)\end{array}$ & $\begin{array}{l}-0.0387 * * * \\
(0.00425)\end{array}$ & $\begin{array}{l}-0.0382 * * * * \\
(0.00422)\end{array}$ & $\begin{array}{l}-0.0389 * * * \\
(0.00423)\end{array}$ & $\begin{array}{l}-0.0379 * * * \\
(0.00427)\end{array}$ & $\begin{array}{l}-0.0388 * * * \\
(0.00424)\end{array}$ & $\begin{array}{l}-0.0389 * * * * \\
(0.00421)\end{array}$ \\
\hline discretion & $\begin{array}{l}0.0259 * * * \\
(0.00325)\end{array}$ & $\begin{array}{l}0.0257^{* * * *} \\
(0.00323)\end{array}$ & $\begin{array}{l}0.0260 * * * * \\
(0.00327)\end{array}$ & $\begin{array}{l}0.0260 * * * \\
(0.00324)\end{array}$ & $\begin{array}{l}0.0259 * * * \\
(0.00326)\end{array}$ & $\begin{array}{l}0.0262^{* * * *} \\
(0.00326)\end{array}$ & $\begin{array}{l}0.0258^{* * * *} \\
(0.00326)\end{array}$ & $\begin{array}{l}0.0259 * * * \\
(0.00325)\end{array}$ \\
\hline pay for performances & $\begin{array}{l}0.0368^{* * * *} \\
(0.00340)\end{array}$ & $\begin{array}{l}0.0372 * * * \\
(0.00340)\end{array}$ & $\begin{array}{l}0.0371 * * * \\
(0.00342)\end{array}$ & $\begin{array}{l}0.0370^{* * * *} \\
(0.00340)\end{array}$ & $\begin{array}{l}0.0373 \text { *** } \\
(0.00343)\end{array}$ & $\begin{array}{l}0.0372 * * * \\
(0.00342)\end{array}$ & $\begin{array}{l}0.0368 * * * \\
(0.00342)\end{array}$ & $\begin{array}{l}0.0369 * * * \\
(0.00341)\end{array}$ \\
\hline training & $\begin{array}{l}0.0222 * * * \\
(0.00290)\end{array}$ & $\begin{array}{l}0.0227 * * * * \\
(0.00289)\end{array}$ & $\begin{array}{l}0.0223 * * * * \\
(0.00292)\end{array}$ & $\begin{array}{l}0.0225 * * * \\
(0.00290)\end{array}$ & $\begin{array}{l}0.0223^{* * * *} \\
(0.00292)\end{array}$ & $\begin{array}{l}0.0224 * * * \\
(0.00291)\end{array}$ & $\begin{array}{l}0.0221 * * * * \\
(0.00291)\end{array}$ & $\begin{array}{l}0.0224 * * * \\
(0.00290)\end{array}$ \\
\hline trust in management & $\begin{array}{l}0.0879 * * * \\
(0.00402)\end{array}$ & $\begin{array}{l}0.0865^{* * * *} \\
(0.00399)\end{array}$ & $\begin{array}{l}0.0883 * * * \\
(0.00403)\end{array}$ & $\begin{array}{l}0.0872^{* * * *} \\
(0.00401)\end{array}$ & $\begin{array}{l}0.0878^{* * * *} \\
(0.00403)\end{array}$ & $\begin{array}{l}0.0876^{* * * *} \\
(0.00402)\end{array}$ & $\begin{array}{l}0.0879 * * * * \\
(0.00402)\end{array}$ & $\begin{array}{l}0.0878 * * * \\
(0.00402)\end{array}$ \\
\hline female & $\begin{array}{l}-0.0186 * * * * \\
(0.00275)\end{array}$ & $\begin{array}{l}-0.0179 * * * \\
(0.00273)\end{array}$ & $\begin{array}{l}-0.0188 * * * * \\
(0.00276)\end{array}$ & $\begin{array}{l}-0.0184 * * * \\
(0.00274)\end{array}$ & $\begin{array}{l}-0.0188 * * * \\
(0.00276)\end{array}$ & $\begin{array}{l}-0.0179 * * * \\
(0.00276)\end{array}$ & $\begin{array}{l}-0.0188 * * * \\
(0.00276)\end{array}$ & $\begin{array}{l}-0.0187 * * * * \\
(0.00275)\end{array}$ \\
\hline employee & $\begin{array}{l}0.115^{* * * *} \\
(0.00323)\end{array}$ & $\begin{array}{l}0.115^{* * * *} \\
(0.00319)\end{array}$ & $\begin{array}{l}0.116^{* * * *} \\
(0.00325)\end{array}$ & $\begin{array}{l}0.115^{* * * *} \\
(0.00321)\end{array}$ & $\begin{array}{l}0.116^{* * * *} \\
(0.00325)\end{array}$ & $\begin{array}{l}0.116^{* * * *} \\
(0.00323)\end{array}$ & $\begin{array}{l}0.116^{* * * *} \\
(0.00324)\end{array}$ & $\begin{array}{l}0.115^{* * * *} \\
(0.00323)\end{array}$ \\
\hline high education & $\begin{array}{l}0.0325 * * * \\
(0.00321)\end{array}$ & $\begin{array}{l}0.0321 * * * \\
(0.00320)\end{array}$ & $\begin{array}{l}0.0324 * * * \\
(0.00323)\end{array}$ & $\begin{array}{l}0.0322 * * * \\
(0.00320)\end{array}$ & $\begin{array}{l}0.0321 * * * \\
(0.00322)\end{array}$ & $\begin{array}{l}0.0327 * * * \\
(0.00322)\end{array}$ & $\begin{array}{l}0.0324 * * * \\
(0.00322)\end{array}$ & $\begin{array}{l}0.0325 * * * \\
(0.00321)\end{array}$ \\
\hline rule of law countries & $\begin{array}{l}0.0123^{* * * *} \\
(0.00460)\end{array}$ & $\begin{array}{l}0.0125 * * * \\
(0.00459)\end{array}$ & $\begin{array}{l}0.0123 * * * \\
(0.00462)\end{array}$ & $\begin{array}{l}0.0122^{* * * *} \\
(0.00459)\end{array}$ & $\begin{array}{l}0.0123^{* * * *} \\
(0.00462)\end{array}$ & $\begin{array}{l}0.0127 * * * \\
(0.00463)\end{array}$ & $\begin{array}{l}0.0123 * * * * \\
(0.00462)\end{array}$ & $\begin{array}{l}0.0121 * * * \\
(0.00460)\end{array}$ \\
\hline age & $\begin{array}{l}-0.00215^{* * * *} \\
(0.000126)\end{array}$ & $\begin{array}{l}-0.00218 * * * \\
(0.000126)\end{array}$ & $\begin{array}{l}-0.00217 * * * \\
(0.000127)\end{array}$ & $\begin{array}{l}-0.00216^{* * *} \\
(0.000126)\end{array}$ & $\begin{array}{l}-0.00217 * * * \\
(0.000127)\end{array}$ & $\begin{array}{l}-0.00219 * * * \\
(0.000127)\end{array}$ & $\begin{array}{l}-0.00218 * * * \\
(0.000127)\end{array}$ & $\begin{array}{l}-0.00215^{* * * *} \\
(0.000126)\end{array}$ \\
\hline Other control variables & & - & - & - & - & - & - & - \\
\hline discrimination & & $\begin{array}{l}-0.0427 * * * \\
(0.00441)\end{array}$ & & & & & & \\
\hline $\begin{array}{l}\text { sexual orientation } \\
\text { discrimination }\end{array}$ & & & $\begin{array}{l}-0.0347 * * \\
(0.0149)\end{array}$ & & & & & \\
\hline age discrimination & & & & $\begin{array}{l}-0.0383^{* * *} \\
(0.00605)\end{array}$ & & & & \\
\hline dis ability dis crimination & & & & & $\begin{array}{l}-0.0470 * * * \\
(0.00970)\end{array}$ & & & \\
\hline gender discrimination & & & & & & $\begin{array}{l}-0.0501 * * * \\
(0.00658)\end{array}$ & & \\
\hline e thnicity discrimination & & & & & & & $\begin{array}{l}-0.0389 * * * \\
(0.00819)\end{array}$ & \\
\hline $\begin{array}{l}\text { intersezionality with sexual } \\
\text { orientation discrimination }\end{array}$ & & & & & & & & $\begin{array}{l}-0.0367 * * \\
(0.0161) \\
\end{array}$ \\
\hline Observations & 43,850 & 43,850 & 43,624 & 43,850 & 43,634 & 43,680 & 43,651 & 43,799 \\
\hline R2 & 0.2499 & 0.2515 & 0.2496 & 0.2506 & 0.2497 & 0.2502 & 0.2500 & 0.2499 \\
\hline
\end{tabular}

Note: Standard errors in parentheses. $* * * \mathrm{p}<0.01,{ }^{*} \mathrm{p}<0.05,{ }^{*} \mathrm{p}<0.1$. Source: our elaboration of EWCS 2015 
Table 2 contains the probit models on the effect of HRM practices on perception of different types of discrimination.

Observing control variables, we note that females have a higher probability of being discriminated on the ground of gender ( $p$-value<0.01) than males. This result can be related to the lower probability of being satisfied with their job, previously showed in Table 1 . On the contrary, women results less likely to report perception of discrimination on the ground of sexual orientation, disability and ethnicity than their male counterpart. The latter may hide adaptive behaviour to discriminatory practices.

Taking into account high education, it has a positive impact only on differently abled people and on immigrants while, for individual discriminated on the ground of the gender, it increases the probability of perceiving discrimination ( $\mathrm{p}$-value $<0.01$ ).

Trust the management reduces the probability of perceiving every kind of discrimination.

We also found that living in one of the five "rule of law" countries reduces the likelihood of being intersectionally discriminated ( $\mathrm{p}$-value $<0.01$ ), discriminated by sexual orientation ( $\mathrm{p}$-value $<0.01$ ), disability $(\mathrm{p}$-value $<0.10)$ and ethnicity (p-value $<0.05)$. At the same time, our findings show that living in one of these countries can increase the probability of perceiving discrimination on the ground of gender ( $\mathrm{p}$-value $<0.05$ ).

With respect to HRM practices and their impact on employees' perception of discrimination, our findings highlight that working in a team endowed with discretion, working with intensity, being subjected to performance pay schemes and to training programmes can increase the probability of perceive discrimination on the ground of each characteristic. From the other side, the presence of supportive co-workers and supervisors can help in reducing the likelihood of perceiving discrimination.

Consistent with the literature (Alvesson and Robertson, 2006; Langfred, 2000; Mazmanian, Orlikowski \& Yates, 2013), autonomy leads to controversial results. Taking into account discrimination in general and age-related discrimination, autonomy decreases the probability of perceiving discrimination but, in the other models, autonomy changes its sign and loses significance ( $\mathrm{p}$-value $>0.10$ ).

These findings partially support our second hypothesis of a decreasing effect of HRM practices on workers' perception of any kind of discrimination, except for work-groups discretion, performance pay schemes and job intensity. We found, indeed, that also being subjected to training programmes can have a negative effect on the perception of discrimination. This result may be due to the fact that only a well-developed job training programme can have a decisive impact on workers' perception of discrimination (Cox and Blake, 1991), while not properly-developed job training may have a controversial effect on employees' perceptions and strengthen a discriminatory climate. Moreover, being required to stay in close contact with a potentially discriminant trainer (co-worker or supervisor) can further increase the likelihood of feeling discriminated against. Another potential cause can be the attempt to impose on employees the culture of standardization and normalization trough training process, in a context where there can also be an issue of discrimination in the access to employer-provided training (Allmang et al. 2019) and the type of training accessed to. 
Table 2. Probit models on the effect of HRM practices on perception of different types of discrimination, in workplace. Dependent variable: perception of discrimination. Marginal effects, 2015

\begin{tabular}{|c|c|c|c|c|c|c|c|}
\hline VARIABLES & $\begin{array}{c}\text { Every kind of } \\
\text { Discriminations }\end{array}$ & $\begin{array}{c}\text { Sexual } \\
\text { Orientation } \\
\text { Discrimination }\end{array}$ & $\begin{array}{c}\text { Age } \\
\text { Discrimination }\end{array}$ & $\begin{array}{c}\text { Disability } \\
\text { Discrimination }\end{array}$ & $\begin{array}{c}\text { Gender } \\
\text { Discrimination }\end{array}$ & $\begin{array}{c}\text { Etnicity } \\
\text { Discrimination }\end{array}$ & $\begin{array}{c}\text { Intersezionality } \\
\text { with sexual } \\
\text { orientation } \\
\text { discrimination } \\
\end{array}$ \\
\hline \multirow[t]{2}{*}{ autonomy } & $-0.00689 * *$ & 0.000914 & $-0.00484 * *$ & 0.000263 & -0.000847 & 0.00225 & 0.00107 \\
\hline & $(0.00351)$ & $(0.00109)$ & $(0.00247)$ & $(0.00147)$ & $(0.00174)$ & $(0.00200)$ & $(0.000970)$ \\
\hline \multirow[t]{2}{*}{ discretion of the team } & $0.0121 * * *$ & 0.000166 & $0.00755^{* * *}$ & $0.00184 * *$ & $0.00389 * * *$ & $0.00391 * * *$ & 0.000472 \\
\hline & $(0.00226)$ & $(0.000601)$ & $(0.00163)$ & $(0.000867)$ & $(0.00111)$ & $(0.00112)$ & $(0.000513)$ \\
\hline \multirow[t]{2}{*}{ colleagues support } & $-0.0375 * * *$ & $-0.00248 * * *$ & $-0.0187 * * *$ & $-0.00740 * * *$ & $-0.0116 * * *$ & $-0.0108 * * *$ & $-0.00194 * * *$ \\
\hline & $(0.00246)$ & $(0.000662)$ & $(0.00178)$ & $(0.000976)$ & $(0.00123)$ & $(0.00124)$ & $(0.000559)$ \\
\hline \multirow[t]{2}{*}{ boss support } & $-0.0232 * * *$ & -0.000699 & $-0.0122 * * *$ & $-0.00182 *$ & $-0.00555^{* * *}$ & $-0.00371 * * *$ & -0.000533 \\
\hline & $(0.00251)$ & $(0.000706)$ & $(0.00181)$ & $(0.00104)$ & $(0.00124)$ & $(0.00130)$ & $(0.000591)$ \\
\hline \multirow[t]{2}{*}{ intensity } & $0.0413 * * *$ & $0.00335^{* *}$ & $0.0248 * * *$ & $0.00512 * * *$ & $0.0191 * * *$ & $0.0119 * * *$ & $0.00376 * * *$ \\
\hline & $(0.00519)$ & $(0.00145)$ & $(0.00391)$ & $(0.00198)$ & $(0.00301)$ & $(0.00270)$ & $(0.00140)$ \\
\hline \multirow[t]{2}{*}{ discretion } & $-0.00680 * * *$ & $-0.00110^{*}$ & -0.00101 & $-0.00196^{* *}$ & 0.00119 & $-0.00395 * * *$ & $-0.000961 *$ \\
\hline & $(0.00237)$ & $(0.000617)$ & $(0.00175)$ & $(0.000885)$ & $(0.00121)$ & $(0.00114)$ & $(0.000521)$ \\
\hline \multirow[t]{2}{*}{ pay for performances } & $0.0126^{* * *}$ & $0.00168 * *$ & $0.00775 * * *$ & $0.00511 * * *$ & $0.00258^{*}$ & 0.00126 & $0.00194 * * *$ \\
\hline & $(0.00273)$ & $(0.000769)$ & $(0.00199)$ & $(0.00118)$ & $(0.00133)$ & $(0.00130)$ & $(0.000702)$ \\
\hline \multirow[t]{2}{*}{ training } & $0.0149 * * *$ & $0.00223 * * *$ & $0.0109 * * *$ & $0.00250 * * *$ & $0.00538 * * *$ & $0.00361 * * *$ & $0.00178 * * *$ \\
\hline & $(0.00243)$ & $(0.000681)$ & $(0.00178)$ & $(0.000940)$ & $(0.00121)$ & $(0.00120)$ & $(0.000583)$ \\
\hline \multirow[t]{2}{*}{ trust in management } & $-0.0230 * * *$ & $-0.00131 *$ & $-0.0107 * * *$ & $-0.00298 * * *$ & $-0.00685^{* * *}$ & $-0.00440 * * *$ & -0.000292 \\
\hline & $(0.00249)$ & $(0.000672)$ & $(0.00182)$ & $(0.000987)$ & $(0.00121)$ & $(0.00127)$ & $(0.000609)$ \\
\hline \multirow[t]{2}{*}{ female } & $0.0114 * * *$ & $-0.00134 * *$ & 0.00220 & $-0.00161 *$ & $0.0169 * * *$ & $-0.00375^{* * *}$ & -0.000766 \\
\hline & $(0.00219)$ & $(0.000589)$ & $(0.00157)$ & $(0.000842)$ & $(0.00121)$ & $(0.00109)$ & $(0.000502)$ \\
\hline \multirow[t]{2}{*}{ high education } & 0.00194 & -0.000670 & -0.00138 & $-0.00274 * * *$ & $0.00347 * * *$ & $-0.00206^{*}$ & -0.000599 \\
\hline & $(0.00240)$ & $(0.000611)$ & $(0.00171)$ & $(0.000858)$ & $(0.00122)$ & $(0.00115)$ & $(0.000518)$ \\
\hline \multirow[t]{2}{*}{ rule of law countries } & 0.00479 & $-0.00288 * * *$ & -0.000116 & $-0.00202 *$ & $0.00505 * *$ & $-0.00344 * *$ & $-0.00199 * * *$ \\
\hline & $(0.00375)$ & $(0.000621)$ & $(0.00257)$ & $(0.00122)$ & $(0.00201)$ & $(0.00160)$ & $(0.000544)$ \\
\hline Other control variables & - & - & - & - & - & - & - \\
\hline Observations & 43,850 & 43,624 & 43,850 & 43,634 & 43,680 & 43,651 & 43,799 \\
\hline
\end{tabular}

Note: Standard errors in parentheses.

$* * * \mathrm{p}<0.01, * * \mathrm{p}<0.05, * \mathrm{p}<0.1$. Source: our elaboration of EWCS 2015.

Finally, to test our last hypothesis, i.e. the perception of discrimination's role in making harder the positive impact of HRM practices on workers' overall job-related satisfaction, we performed a series of regression equations. Results, exposed in Table 3, show that in the models related to:

- Perception of sexual orientation discrimination, only the interaction with discretion of the team $(\beta=$ -0.0388 ; $p$-value $<0.10)$ and with on the job training $(B=-0.0397$; $p$-value $<0.10)$ are statistically significant. This may be related to a higher negative impact of working in a team characterized by discretion or in a close relation with trainees with a higher probability that this feeling shows mostly in lower groups interaction than in other HRM practices;

- Perception of gender, age, ethnicity and disability discrimination, all the interactions are statistically significant, except for job intensity in the cases of gender, age and ethnicity discrimination, and except for discretion in the specific case of age discrimination.

In the light of our findings, we argue that perception of discrimination moderates the impact of HRM practices on job satisfaction. This result supports our fourth hypothesis. 
Table 3. Probit models on the effect of interaction between perception of discrimination and HRM practices on job satisfaction. Dependent variable: workers' job satisfaction. Marginal effects, 2015

\begin{tabular}{|c|c|c|c|c|c|}
\hline VARIABLES & Sexual Orientation & Gender & Age & Disability & Ethnicity \\
\hline autonomy & $\begin{array}{r}0.0905^{* * * *} \\
(0.00600)\end{array}$ & $\begin{array}{r}0.0914^{* * * *} \\
(0.0060)\end{array}$ & $\begin{array}{r}0.0913 * * * \\
(0.0060)\end{array}$ & $\begin{array}{r}0.0907 * * * \\
(0.0059)\end{array}$ & $\begin{array}{r}0.0907 * * * * \\
(0.0060)\end{array}$ \\
\hline autonomy*discrimination & $\begin{array}{r}-0.0343 \\
(0.0373)\end{array}$ & $\begin{array}{r}-0.0559 * * * * \\
(0.0137)\end{array}$ & $\begin{array}{r}-0.0432 * * \\
(0.0146)\end{array}$ & $\begin{array}{r}-0.0716^{* *} \\
(0.0129)\end{array}$ & $\begin{array}{c}-0.0414^{*} \\
(0.0187)\end{array}$ \\
\hline discretion of the team & $\begin{array}{r}-0.0066 * * * * \\
(0.0029)\end{array}$ & $\begin{array}{r}-0.0055^{* *} \\
(0.0028)\end{array}$ & $\begin{array}{c}-0.0053 * \\
(0.0028)\end{array}$ & $\begin{array}{r}-0.0061 * * \\
(0.0028)\end{array}$ & $\begin{array}{r}-0.0057 * * \\
(0.0029)\end{array}$ \\
\hline discrteam*discrimination & $\begin{array}{c}-0.0388^{*} \\
(0.0181)\end{array}$ & $\begin{array}{r}-0.0523 * * * * \\
(0.0075)\end{array}$ & $\begin{array}{r}-0.0372 * * * \\
(0.0073)\end{array}$ & $\begin{array}{r}-0.0501 * * * \\
(0.0115)\end{array}$ & $\begin{array}{r}-0.0516 * * * \\
(0.0084)\end{array}$ \\
\hline colleagues support & $\begin{array}{r}0.0802 \\
(0.0036)\end{array}$ & $\begin{array}{r}0.0809^{* * * *} \\
(0.0036)\end{array}$ & $\begin{array}{r}0.0809 * * * * \\
(0.0036)\end{array}$ & $\begin{array}{r}0.0804 * * * * \\
(0.0036)\end{array}$ & $\begin{array}{r}0.0806 * * * * \\
(0.0036)\end{array}$ \\
\hline colleagues*discrimination & $\begin{array}{l}-0.0362 \\
(0.0202)\end{array}$ & $\begin{array}{r}-0.0483 * * * * \\
(0.0092)\end{array}$ & $\begin{array}{r}-0.0286 * * * * \\
(0.0092)\end{array}$ & $\begin{array}{r}-0.0488 * * * * \\
(0.0132)\end{array}$ & $\begin{array}{r}-0.0396 * * * \\
(0.0114)\end{array}$ \\
\hline boss support & $\begin{array}{r}0.0997 * * * \\
(0.0041)\end{array}$ & $\begin{array}{r}0.1000^{* * * *} \\
(0.0041)\end{array}$ & $\begin{array}{r}0.1001 * * * \\
(0.0041)\end{array}$ & $\begin{array}{r}0.0993 * * * \\
(0.0041)\end{array}$ & $\begin{array}{r}0.0996 * * * \\
(0.0041)\end{array}$ \\
\hline boss*discrimination & $\begin{array}{r}-0.0109 \\
(0.0288)\end{array}$ & $\begin{array}{r}-0.0555 * * * \\
(0.0089)\end{array}$ & $\begin{array}{r}-0.0406 * * * \\
(0.0093)\end{array}$ & $\begin{array}{r}-0.0411 * * \\
(0.0158)\end{array}$ & $\begin{array}{r}-0.0410^{* * * *} \\
(0.0121)\end{array}$ \\
\hline intensity & $\begin{array}{r}-0.0387 * * * \\
(0.0042)\end{array}$ & $\begin{array}{r}-0.0381 * * * \\
(0.0043)\end{array}$ & $\begin{array}{r}-0.3769 * * * \\
(0.0043)\end{array}$ & $\begin{array}{r}-0.0382 * * * * \\
(0.0042)\end{array}$ & $\begin{array}{r}-0.0379 * * * \\
(0.0043)\end{array}$ \\
\hline intensity*discrimination & $\begin{array}{l}-0.0251 \\
(0.0499)\end{array}$ & $\begin{array}{r}-0.0268 \\
(0.0222)\end{array}$ & $\begin{array}{l}-0.0315 \\
(0.0195)\end{array}$ & $\begin{array}{l}-0.0707^{*} \\
(0.0200)\end{array}$ & $\begin{array}{r}-0.0507 \\
(0.0224)\end{array}$ \\
\hline discretion & $\begin{array}{r}0.0261 * * * \\
(0.0032)\end{array}$ & $\begin{array}{r}0.0268^{* * * *} \\
(0.0032)\end{array}$ & $\begin{array}{r}0.0264 * * * \\
(0.0032)\end{array}$ & $\begin{array}{r}0.0263 * * * \\
(0.0032)\end{array}$ & $\begin{array}{r}0.0264 * * * * \\
(0.0032)\end{array}$ \\
\hline discretion*discrimination & $\begin{array}{l}-0.0327 \\
(0.0294)\end{array}$ & $\begin{array}{r}-0.0392 * * * \\
(0.0112)\end{array}$ & $\begin{array}{l}-0.0175 \\
(0.0119)\end{array}$ & $\begin{array}{r}-0.0497 * * \\
(0.0167)\end{array}$ & $\begin{array}{r}-0.0407^{* * *} \\
(0.1420)\end{array}$ \\
\hline pay for performances & $\begin{array}{r}0.0372 * * * * \\
(0.0034)\end{array}$ & $\begin{array}{r}0.0381 * * * \\
(0.0034)\end{array}$ & $\begin{array}{r}0.0386^{* * * *} \\
(0.0034)\end{array}$ & $\begin{array}{r}0.0375^{* * * *} \\
(0.0034)\end{array}$ & $\begin{array}{r}0.0376^{* * * *} \\
(0.0034)\end{array}$ \\
\hline payperf*discrimination & $\begin{array}{l}-0.0298 \\
(0.0238)\end{array}$ & $\begin{array}{r}-0.0509^{* * * *} \\
(0.0101)\end{array}$ & $\begin{array}{r}-0.0440 * * * * \\
(0.0087)\end{array}$ & $\begin{array}{r}-0.0444 * * \\
(0.0144)\end{array}$ & $\begin{array}{r}-0.0439 * * * * \\
(0.0125)\end{array}$ \\
\hline training & $\begin{array}{r}0.0224 * * * * \\
(0.0029)\end{array}$ & $\begin{array}{r}0.2317 * * * \\
(0.0029)\end{array}$ & $\begin{array}{r}0.0231 * * * * \\
(0.0029)\end{array}$ & $\begin{array}{r}0.0227^{* * * *} \\
(0.0029)\end{array}$ & $\begin{array}{r}0.0228 * * * \\
(0.0029)\end{array}$ \\
\hline training*discrimination & $\begin{array}{c}-0.0397^{*} \\
(0.0159)\end{array}$ & $\begin{array}{r}-0.0509 * * * \\
(0.0073)\end{array}$ & $\begin{array}{r}-0.0316 * * * \\
(0.0075)\end{array}$ & $\begin{array}{r}-0.0486^{* * * *} \\
(0.0116)\end{array}$ & $\begin{array}{r}-0.0341^{* * * *} \\
(0.0104) \\
\end{array}$ \\
\hline
\end{tabular}

Note: The models include HRM practices and socio demographic variables. Standard errors in parentheses.

$* * * \mathrm{p}<0.01, * * \mathrm{p}<0.05, * \mathrm{p}<0.1$. Source: our elaboration of EWCS 2015.

\section{Discussion, Limitation and Further Research}

One of the aims of this essay was to detect determinants of perceived discrimination in the workplace with a special focus on HRM practices and their outcomes. Our results confirm that discrimination in the workplace is most frequently perceived in presence of some specific HRM practices and outcomes, in particular job intensity, performance pay schemes and self-managed work groups and that it impacts negatively on workers' job satisfaction. This represents a relevant contribution to current literature on the issue of inclusiveness and wellbeing in workplaces. To the best of our knowledge, our research is the first scholarly attempt to quantitatively investigate the above issue by tracing a clear distinction between different kind of discriminations and HRM practices.

Moreover, our findings provide support for those scholars working on the relation between the implementation of some specific HRM practices and workers' overall job satisfaction, suggesting that this relation can be moderated by the presence of perceived discrimination. 
We believe that these results contribute to the literature by extending prior findings in four ways. Firstly, our findings provide support for those scholars investigating the effects of HRM practices on employees' job satisfaction. We found that work overload, time pressure, tight deadlines and high-speed work directly contribute to decrease job-related satisfaction, consistently with literature. Moreover, the present study supports the Discretion Paradox in work-groups, which reflects the trade-off between workers' interest in personal discretion and the possible highest level of control and judgment acted by colleagues. More specifically, our findings show that working in self-managed teams increases the probability of perceiving any kind of discrimination and of reporting low levels of job satisfaction, consistently with Barker (1999). Our results also demonstrate that colleagues and supervisors' support is the most effective HRM practice for increasing a feeling of belongingness to the company that impacts, consequently, on job satisfaction, as well as on the very perception of discrimination. Even if there is no consensus on the categorization of boss and co-workers support into the basket of HRM practices, we decided to use this element thanks to its nature: it can be, indeed, the result of a precise inclusive-oriented organizational policy.

Secondly, our research helps to identify which HRM practices can increase the likelihood of perceiving discrimination in the workplace. Our results show that self-managed teams, job- intensity and pay-for-performance schemes can increase the likelihood of perceiving discrimination on the ground of each characteristic. From the other side, the presence of supportive co-workers and supervisors can help in reducing the likelihood of perceiving discrimination, as mentioned above.

Another result of our study concerns the ambiguity of the autonomy effect, a result that is consistent with the literature (Alvesson and Robertson, 2006; Albano et al., 2018). In fact, by taking into account discrimination in general and age-related discrimination, it decreases the probability of perceiving discrimination but, in the presence of other types of discriminations, autonomy changes its sign and loses significance. Another important contribution of our study can be identified in terms of deepening the training programmes' role as perception of discriminations' deterrent. Contrary to the expectation, being subjected to training programmes can, indeed, have a negative effect on the perception of discrimination. This result may be due to the fact that only well-developed job training programmes can have decisive effects on workers' perception of discrimination (Cox and Blake, 1991), while not properly-developed job training may controversially impact on employees' perceptions and feelings. Moreover, being required to stay in close contact with a potentially discriminant trainer (co-worker or supervisor) can further increase the likelihood of feeling discriminated against. Given the positive effect that on the job training can have on employee's skills acquisition and career advancement and, more in general, on firm's productivity more attention should be paid to the interaction between perceived discrimination and training in order to limit the negative effect on the very access to on-the-job training.

Thirdly, in showing that perceived discrimination can have a negative effect on job satisfaction, our study demonstrates that perception of sexual orientation discrimination is the one with the lower marginal effect. As highlighted by UNAR (2014) and mentioned in section 2, this result can be explained by the fact that sexual orientation is not readily observable and individuals may not experience direct discrimination in the short term. Several scholars have shown that "coming out" at work, declaring sexual orientation to colleagues and supervisors, can expose LGB employees to discrimination and hostility in the workplace (Hebl, Law, \& King, 2010; Ragins \& Cornwell, 2001). At the same time, hiding their own sexual orientation in order to avoid stigma, LGB workers expose themselves to isolation, high level of stress, lowered sense of belonging and even actual social rejection (Goffman, 1963; Newheiser \& Barreto, 2015). In the light of this, even if perception of sexual orientation discrimination appears to be the one less related to job satisfaction, it must not be forgotten that its "invisibility" doesn't makes it easier to manage.

Finally, with respect to studies that observe the impact of HRM practices on job satisfaction, taking into account workers' perceived discrimination, our findings extend the body of the literature showing that workers discriminated on the ground of different characteristics need diverse HRM practices with a view to their inclusion and, afterwards, with regard to their job satisfaction. In details, our findings indicate that reducing job intensity, developing well-done training programmes and restricting the work in self-managed group can be more efficient than implementing other HRM practices in the case of sexual orientation discrimination. It must be noted, on this regard, that job-training and team discretion, have been found to be the only on HRM practices that decrease job satisfaction if the worker perceives sexual orientation discrimination, showing a higher exposure of lower job satisfaction if the worker feeling to be discriminated for sexual orientation is in close relation in a team with higher discretion or in the interaction with a potentially discriminant trainer or trainees.

For the inclusion of those workers who perceive other kinds of discrimination, our results also highlight the positive impact of increasing individual discretion, except for age-discrimination. This can be explained by the 
fact that older workers have already been equipped with a relatively high level of discretion, due to higher seniority.

There are limitations to this research and its results. In particular, it is strongly based on individual employees' perceptions gathered through a large-scale survey that gave no specific details about discrimination suffered. Using self-reported data implies a limited description of the working reality analysed. Other limitations of the present study are common method bias (CMB) and reverse causality due to the use of cross sectional data collected from a single respondent. Moreover, the European Working Condition Survey (2015) doesn't contain information about respondents' sexual orientation and their eventual coming out at work. These boundaries severely limit the deepening of the analysis of sexual orientation perception of discrimination in workplace and its consequences on employee attitudes, feelings, behaviours and performances.

Although we have clearly demonstrated the importance of analysing the relationship between HRM practices and job satisfaction, taking into account workers' perception of different kinds of discrimination, there is still much work to be done in gaining a better knowledge of these connections. Future studies which use more detailed methods of data collection are needed, in particular research efforts counting the detectability of indicators to assess discrimination and all its forms, causes and effects in workplace. We also suggest expanding the field of research, performing more complex models which can include national anti-discriminatory law indicators together with workers' perceived discrimination and cluster HRM practices according to their inclusiveness content. This would allow us to analyse more paths of the relation between HRM practices, individual behaviours and organizational outcomes, measuring the extent to which HRM practices, through the moderating effect of perception of discrimination, influence workers' overall job satisfaction.

\section{References}

Ahmed, A., Andersson, L., \& Hammarstedt, M. (2012). Sexual prejudice and labor market outcomes of gays and lesbians. Linnaeus University.

Akkerman, A., Kef, S., \& Meininger, H. P. (2018). Job satisfaction of people with intellectual disabilities: The role of basic psychological need fulfillment and workplace participation. Disability and rehabilitation, 40(10), 1192-1199. https://doi.org/10.1080/09638288.2017.1294205

Albano, R., Curzi, Y., Parisi, T., \& Tirabeni, L. (2018). Perceived autonomy and discretion of mobile workers. Studi organizzativi. https://doi.org/10.3280/SO2018-002002

Albert, R., Escot, L., \& Fernández-Cornejo, J. A. (2011). A field experiment to study sex and age discrimination in the Madrid labour market. The International Journal of Human Resource Management, 22(02), 351-375. https://doi.org/10.1080/09585192.2011.540160

Aldén, L., Hammarstedt, M., \& Swahnberg, H. (2020). Sexual Orientation and Job Satisfaction: Survey-Based Evidence from Sweden. Journal of Labor Research, 1-33. https://doi.org/10.1007/s12122-019-09297-w

Allen, D. G., Shore, L. M., \& Griffeth, R. W. (2003). The role of perceived organizational support and supportive human resource practices in the turnover process. Journal of Management, 29, 99-118. https://doi.org/10.1177/014920630302900107

Allen, R. E., \& Keaveny, T. J. (1985). Factors differentiating grievants and nongrievants. Human Relations, 38(6), 519-534. https://doi.org/10.1177/001872678503800602

Allmang, S., Jou, J., Gadoth, A., Rozhenkova, V., Raub, A., \& Heymann, J. (2019). Legislative Protection from Discrimination in Access to Employer-Provided Training. International Journal of Training and Development, 23(4), 276-290. https://doi.org/10.1111/ijtd.12162

Altaf, A., \& Awan, M. A. (2011). Moderating affect of workplace spirituality on the relationship of job overload and job satisfaction. Journal of business ethics, 104(1), 93-99. https://doi.org/10.1007/s10551-011-0891-0

Alvesson, M., \& Robertson, M. (2006). The best and the brightest: The construction, significance and effects of elite identities in consulting firms. Organization, 13(2), 195-224. https://doi.org/10.1177/1350508406061674

Anuar, A., Ismail, A., \& Abdin, F. (2014). Administrator's role in performance pay system as a determinant of job satisfaction. Sains Humanika, 2(2).

Appelbaum, E., Bailey, T., Berg, P., \& Kalleberg, A. (2000). Manufacturing advantage: Why high performance work systems pay off. Ithaca, NY: Cornell University Press.

Armstrong, M., \& Baron, A. (2005). Managing performance: performance management in action. CIPD 
publishing.

Armstrong, M. (2006). A handbook of human resource management practice. Kogan Page Publisher.

Badgett, L. M. V. (1996). Employment and sexual orientation: Disclosure and discrimination in the workplace. Journal of Gay and Lesbian Social Services, 4(4), 29-52. https://doi.org/10.1300/J041v04n04_03

Badgett, L. M. V., \& Frank, J. (2007). Sexual Orientation Discrimination: An International Perspective. New York: Routledge. https://doi.org/10.4324/9780203086650

Badgett, L. M. V., Lau, H., Sears, B., \& Ho, D. (2007). Bias in the Workplace: Consistent Evidence of Sexual Orientation and Gender Identity Discrimination. The Williams Institute, UCLA School of Law.

Barker, J. R. (1999). The discipline of teamwork: Participation and concretive control. Sage Publications.

Baron, R. M., \& Kenny, D. A. (1986). The moderator-mediator variable distinction in social psychological research: Conceptual, strategic, and statistical considerations. Journal of personality and social psychology, 51(6), 1173. https://doi.org/10.1037/0022-3514.51.6.1173

Bartel, A. P. (1994). Productivity gains from the implementation of employee training programs. Industrial Relation, 33, 411-425. https://doi.org/10.1111/j.1468-232X.1994.tb00349.x

Bartling, B., Fehr, E., \& Schmidt, K. M. (2013). Discretion, productivity, and work satisfaction. Journal of Institutional and Theoretical Economics JITE, 169(1), 4-22. https://doi.org/10.1628/093245613X660357

Bender, K. A., Donohue, S. M., \& Heywood, J. S. (2005). Job satisfaction and gender segregation. Oxford economic papers, 57(3), 479-496. https://doi.org/10.1093/oep/gpi015

Boehm, S. A. et al. (2014). Expanding insights on the diversity climate-performance link: The role of workgroup discrimination and group size. Human Resource Management, 53(3), 379-402. https://doi.org/10.1002/hrm.21589

Buchanan, N. T. et al. (2009). Unique and joint effects of sexual and racial harassment on college students' well-being. Basic and Applied Social Psychology, 31, 267-285. https://doi.org/10.1080/01973530903058532

Buijs, F. J., Demant, F., \& Hamdy, A. (2006). Strijders van eigen bodem: Radicale en democratische Moslims in Nederland. [Home grown fighters: Radical and democratic Muslims in the Netherlands]. Amsterdam, Netherlands: Amsterdam University Press. https://doi.org/10.21825/agora.v23i1.9997

Burke, R. J. (1995). Management practices, employees' satisfaction and perceptions of quality service. Psychological Reports, 77, 748-50. https://doi.org/10.2466/pr0.1995.77.3.748

Cardarelli, R. et al. (2007). Modifying effects of education and income on Hispanics reporting perceived discrimination. Hispanic Journal of Behavioral Sciences, 29(3), 401-407. https://doi.org/10.1177/0739986307303237

Carpenter, C. S. (2005). Sexual orientation and economic well-being in Canada. Canadian Journal of Economics, Article in Press. Retrieved from http://web. gsm. uci. edu/ kittc/CarpenterCanadaGLB. pdf

Channar, Z. A., Abbassi, Z., \& Ujan, I. A. (2011). Gender discrimination in workforce and its impact on the employees. Pakistan Journal of Commerce and Social Sciences (PJCSS), 5(1), 177-191.

Chou, R. J. A., \& Choi, N. G. (2011). Prevalence and correlates of perceived workplace discrimination among older workers in the United States of America. Ageing and Society, 31(6), 1051-1070. https://doi.org/10.1017/S0144686X10001297

Colella, A., \& King, E. (Eds.). (2018). The Oxford handbook of workplace discrimination. Oxford University Press.

Conrade, G., \& Woods, R. N. (1994). Training in the U.S. lodging industry: Perception and reality. Cornell Hotel and Restaurant Administration Quarterly, 35(5), 16-21. https://doi.org/10.1177/001088049403500511

Cox, T. H., \& Blake, S. (1991). Managing cultural diversity: Implications for organizational competitiveness. Academy of Management Perspectives, 5(3), 45-56.

https://doi.org/10.5465/ame.1991.4274465

Crenshaw, K. (1989). Demarginalizing the intersection of race and sex: a Black feminist critique of antidiscrimination doctrine, feminist theory and antiracist politics. University of Chicago Legal Forum, 
139-168.

Day, N. E., \& Greene, P. G. (2008). A case for sexual orientation diversity in small and large organizations. Human Resource Management, 47(3), 637-654. https://doi.org/10.1002/hrm.20235

Doubbelaere, A., \& Goeppinger, K. (1991). Demographic Challenges. Employee Benefits Journal, 7-13.

Driscoll, J. M., Kelley, F. A., \& Fassinger, R. E. (1996). Lesbian identity and disclosure in the workplace: Relation to occupational stress and satisfaction. Journal of Vocational Behavior, 48(2), 229-242. https://doi.org/10.1006/jvbe.1996.0020

Drydakis, N. (2012). Men's sexual orientation and job satisfaction. International Journal of Manpower. https://doi.org/10.1108/01437721211280371

Drydakis, N. (2015). Effect of sexual orientation on job satisfaction: Evidence from Greece. Industrial Relations: A Journal of Economy and Society, 54(1), 162-187. https://doi.org/10.1111/irel.12080

Ducharme, L. J., \& Martin, J. K. (2000). Unrewarding work, coworker support, and job satisfaction: A test of the buffering hypothesis. Work and occupations, 27(2), 223-243. https://doi.org/10.1177/0730888400027002005

Duraisamy, M., \& Duraisamy, P. (2016). Gender wage gap across the wage distribution in different segments of the Indian labour market, 1983-2012: exploring the glass ceiling or sticky floor phenomenon. Applied Economics, 48(43), 4098-4111. https://doi.org/10.1080/00036846.2016.1150955

Durham, C. C., Knight, D., \& Locke, E. A. (1997). Effects of leader role, team-set goal difficulty, efficacy, and tactics on team effectiveness. Organizational Behavior and Human Decision Processes, 72(2), 203-231. https://doi.org/10.1006/obhd.1997.2739

Easterlin, R. A. (2001). Income and happiness: towards a unified theory. Economic Journal, 111(473), 465-84. https://doi.org/10.1111/1468-0297.00646

Ellis, A. L., \& Riggle, E. D. (1996). The Relation of Job Satisfaction and Degree of Openness About Ones' Sexual Orientation for Lesbians and Gay Men. Journal of homosexuality, 30(2), 75-85. https://doi.org/10.1300/J082v30n02_04

Engel, G. V. (1970). Professional autonomy and bureaucratic organization. Administrative Science Quarterly 15(1), 12-21. https://doi.org/10.2307/2391182

Ensher, E. A., Grant-Vallone, E. J., \& Donaldson, S. I. (2001). Effects of perceived discrimination on job satisfaction, organizational commitment, organizational citizenship behavior, and grievances. Human resource development quarterly, 12(1), 53-72. https://doi.org/10.1002/1532-1096(200101/02)12:1<53::AID-HRDQ5>3.0.CO;2-G

Entzinger, H., \& Dourleijn, E. (2008). De lat steeds hoger: De leefwereld van jongeren in een multi-etnische stad. Assen, Netherlands: Van Gorcum.

Eurofound. (2016). Sixth European Working Conditions Survey: Overview report.

European Industrial Relations Observatory. (2000). Industrial relations and the ageing workforce: the case of Finland. EIROnline.

European Union Agency for Fundamental Rights. (2009). Homophobia and Discrimination on Grounds of Sexual Orientation and Gender Identity in the European Union Member States: Part II-The Social Situation. European Union: Vienna.

Federal Glass Ceiling Commission. (1995). Good for business: Making full use of the nation's human capital. Washington, DC: Author.

French, J. R. P., Jr., Rodgers, W., \& Cobb, S. (1974). Adjustment as person-environment fit. In Coelho, G. V., Hamburg, D. A., \& Adams, J. E. (Eds.), CopingandAdaptation, Basic Books, New York.

Furunes, T., \& Mykletun, R. J. (2010). Age discrimination in the workplace: Validation of the Nordic Age Discrimination Scale (NADS). Scandinavian Journal of Psychology, 51(1), 23-30. https://doi.org/10.1111/j.1467-9450.2009.00738.x

Georgellis, Y., Lange, T., Petrescu, A. I., \& Simmons, R. (2008). Human resource management practices and workers' job satisfaction. International Journal of Manpower.

Gibson, F. K., \& Teasley, C. E. (1973). The Humanistic Model of Organizational Motivation: A Review of 
Research Support. Public Administration Review, 33, 89-96. https://doi.org/10.2307/974790

Goffman, E. (1963). Stigma: Notes on the management of a spoiled identity. Englewood Cliffs, NJ: Prentice-Hall.

Green, C. P., Heywood, J. S., Kler, P., \& Leeves, G. (2018). Paradox lost: The disappearing female job satisfaction premium. British Journal of Industrial Relations, 56(3), 484-502. https://doi.org/10.1111/bjir.12291

Green, C., \& Heywood, J. S. (2008). Does performance pay increase job satisfaction? Economica, 75(300), 710-728. https://doi.org/10.1111/j.1468-0335.2007.00649.x

Griffin, M. A., Patterson, M. G., \& West, M. A. (2001). Job satisfaction and teamwork: The role of supervisor support. Journal of Organizational Behavior, 22, 537-550. https://doi.org/10.1002/job.101

Hammarstedt, M., Aldén, L., \& Swahnberg, H. (2018). (I Can't Get No) Job Satisfaction? Differences by Sexual Orientation in Sweden. Research Institute of Industrial Economics, IFN Working Paper No. 1241.

Hanaysha, J., \& Tahir, P. R. (2016). Examining the effects of employee empowerment, teamwork, and employee training on job satisfaction. Procedia-Social and Behavioral Sciences, 219, 272-282. https://doi.org/10.1016/j.sbspro.2016.05.016

Hebl, M. R., Law, C. L., \& King, E. (2010). Heterosexism. The handbook of prejudice, stereotyping, and discrimination. Thousand Oaks, CA: Sage.

Heskett, J. L., Jones, T. O., Loveman, G. W., Sasser, W. E., \& Schlesinger, L. A. (1994). Putting the service-profit chain to work. Harvard Business Review 71(2), 164-74.

Hogg, M. A., \& Terry, D. J. (2000). Social identity and self-categorization processes in organizational contexts. Academy of Management Review, 25, 121-140. https://doi.org/10.5465/amr.2000.2791606

Hollenbeck, J. R., Noe, R. A., \& Gerhart, B. A. (2018). Human resource management: Gaining a competitive advantage. McGraw-Hill Education.

Hopkins, A. H. (1980). Perceptions of employment discrimination in the public sector. Public Administration Review, 131-137. https://doi.org/10.2307/975623

Huebner, D. M., \& Davis, M. C. (2005). Gay and bisexual men who disclose their sexual orientations in the workplace have higher workday levels of salivary cortisol and negative affect. Annals of Behavioral Medicine, 30(3), 260-267. https://doi.org/10.1207/s15324796abm3003_10

Ileana Petrescu, A., \& Simmons, R. (2008). Human resource management practices and workers' job satisfaction. International journal of manpower, 29(7), 651-667. https://doi.org/10.1108/01437720810908947

Innocenti, L., Pilati, M., \& Peluso, A. M. (2011). Trust as moderator in the relationship between HRM practices and employee attitudes. Human Resource Management Journal, 21(3), 303-317. https://doi.org/10.1111/j.1748-8583.2010.00151.x

Jackson, S. E., \& Schuler, R. S. (1995). Understanding human resource management in the context of organizations and their environments. Annual review of psychology, 46(1), 237-264. https://doi.org/10.1146/annurev.ps.46.020195.001321

Jayaratne, S. (1993). The antecedents, consequences, and correlates of job satisfaction. In R. T. Golembiewski (Ed.), Handbook of organizational behavior. New York: Marcel Dekker.

Karasek, R. (1985). Job content questionnaire. Los Angeles: Department of Industrial Systems Engineering, University of Southern California.

Kim, H., Lee, J. K., \& Sung, S. (2013). The effects of family-friendly practices and gender discrimination on job attitudes: The moderating role of supervisor support. The International Journal of Human Resource Management, 24(20), 3921-3938. https://doi.org/10.1080/09585192.2013.789442

King, E. B., Dawson, J. F., Kravitz, D. A., \& Gulick, L. M. (2012). A multilevel study of the relationships between diversity training, ethnic discrimination and satisfaction in organizations. Journal of Organizational Behavior, 33(1), 5-20. https://doi.org/10.1002/job.728

Kocman, A., \& Weber, G. (2018). Job satisfaction, quality of work life and work motivation in employees with intellectual disability: A systematic review. Journal of Applied Research in Intellectual Disabilities, 31(1), 1-22. https://doi.org/10.1111/jar.12319 
Kopelman, R. E., Brief, A. P., \& Guzzo, R. A. (1990). The role of climate and culture in productivity. Organizational climate and culture, 282, 318.

Koustelios, A. D., \& Bagiatis, K. (1997). The employee satisfaction inventory (ESI): Development of a scale to measure satisfaction of Greek employees. Educational and Psychological Measurement, 57(3), 469-476. https://doi.org/10.1177/0013164497057003008

Lait, J., \& Wallace, J. E. (2002). A study of organizational-professional conflict and unmet expectations. Stress Work, 57(3), 463-487. https://doi.org/10.7202/006886ar

Landy, F. J. (1985). Psychology of work behavior. Homewood, IL: Dorsey Press.

Lewin, K., Lippitt, R., \& White, R. K. (1939). Patterns of aggressive behavior in experimentally created "social climates". The Journal of social psychology, 10(2), 269-299.

https://doi.org/10.1080/00224545.1939.9713366

Locke, E. A. (1976). The nature and causes of job satisfaction. In M. D. Dunnette (Ed.), Handbook of industrial and organizational psychology (pp. 1297-1349). Chicago: Rand McNally.

Lorenzetti, A., \& Viggiani, G. (2016). Hard Work, LGBT persons in the workplace in Italy. ETS.

Maggi, B. (2016). De l'agir organisationnel. Un point du vue sur le travail, le bien-etre, l'apprentissage, Octares, Toulouse (TAO Digital Library, Bologna, 2016, $2^{\mathrm{a}}$ ed.).

Miller, G. V. F., \& Travers, C. J. (2005). Ethnicity and the experience of work: Job stress and satisfaction of minority ethnic teachers in the UK. International Review of Psychiatry, 17(5), 317-327. https://doi.org/10.1080/09540260500238470

Moore, S., Wright, T., \& Conley, H. (2012). Addressing discrimination in the workplace on multiple grounds: The experience of trade union equality reps. E-prints. Uwe. https://doi.org/10.1093/indlaw/dwr025

Nadler, J. T., Voyles, E. C., Cocke, H., \& Lowery, M. R. (2016). Gender disparity in pay, work schedule autonomy and job satisfaction at higher education levels. North American Journal of Psychology, 18(3), 623.

Newheiser, A. K., \& Barreto, M. (2014). Hidden costs of hiding stigma: Ironic interpersonal consequences of concealing a stigmatized identity in social interactions. Journal of Experimental Social Psychology, 52, 58-70. https://doi.org/10.1016/j.jesp.2014.01.002

Offermann, L. R., \& Basford, T. E. (2013). Inclusive Human Resource Management: Best Practices and the Changing Role of Human Resources, Ch.8. In Barbara R. Deane, \& Bernardo, M. F. (Eds.), Diversity at Work: The Practice of Inclusion. Jossey-Bass, pp. 229-259. https://doi.org/10.1002/9781118764282.ch8

Oliviero, S., Maria Sicca, L., \& Valerio, P. (2015). Trans-formare le pratiche nelle organizzazioni di lavoro e di pensiero. Editoriale Scientifica. Napoli.

Ostroff, C., \& Bowen, D. E. (2000). Moving HR to a higher level: HR practices and organizational effectiveness.

Ozeren, E. (2014). Sexual orientation discrimination in the workplace: A systematic review of literature. Procedia-Social and Behavioral Sciences, 109(8), 1203-1215. https://doi.org/10.1016/j.sbspro.2013.12.613

Pagan, R. (2011). Ageing and disability: Job satisfaction differentials across Europe. Social science and medicine, 72(2), 206-215. https://doi.org/10.1016/j.socscimed.2010.11.007

Pagan, R. (2013). Job satisfaction and domains of job satisfaction for older workers with disabilities in Europe. Journal of Happiness Studies, 14(3), 861-891. https://doi.org/10.1007/s10902-012-9359-x

Patacchini, E., Ragusa, G., \& Zenou, Y. (2015). Unexplored dimensions of discrimination in Europe: Homosexuality and physical appearance. Journal of Population Economics, 28(4), 1045-1073. https://doi.org/10.1007/s00148-014-0533-9

Perry, E. L., Hendricks, W., \& Broadbent, E. (2000). An exploration of access and treatment discrimination and job satisfaction among college graduates with and without physical disabilities. Human Relations, 53(7), 923-955. https://doi.org/10.1177/0018726700537002

Pilati, M., \& Innocenti, L. (2008). Pratiche di gestione delle risorse umane, performance individuali e comportamenti organizzativi. In IX Workshop dei Docenti e dei Ricercatori di Organizzazione Aziendale, Venezia. 
Purdie-Vaughns, V., \& Eibach, R. P. (2008). Intersectional invisibility. Sex Roles, 59, 377-391. https://doi.org/10.1007/s11199-008-9424-4

Ragins, B. R., \& Cornwell, J. M. (2001). Pink triangles: antecedents and consequences of perceived workplace discrimination against gay and lesbian employees. Journal of applied psychology, 86(6), 1244. https://doi.org/10.1037/0021-9010.86.6.1244

Reicher, A., \& Schneider, B. (1990). Climate and Culture: a evolution of constructs.

Robertson, M., Scarbrough, H., \& Swan, J. (2003). Knowledge creation in professional service firms: Institutional effects. Organization Studies, 24(6), 831-857. https://doi.org/10.1177/0170840603024006002

Russo, T., \& Valerio, P. (2019). Transgenderismo e identità di genere: dai manuali nosografici ai contesti. Un focus sulle università italiane. Rivista Sperimentale Di Freniatria, II, 79-112. https://doi.org/10.3280/RSF2019-002005

Sanchez, J. I., \& Brock, P. (1996). Outcomes of Perceived Discrimination among Hispanic Employees: Is Diversity Management a Luxury or a Necessity? Academy of Management Journal, 39, 704-719. https://doi.org/10.2307/256660

Saxena, A. (2014). Workforce diversity: A key to improve productivity. Procedia Economics and Finance, 11, 76-85. https://doi.org/10.1016/S2212-5671(14)00178-6

Schaufeli, W. B., \& Toon, W. T. (2014). A critical review of the job demands-resources model: Implications for improving work and health. Bridging occupational, organizational and public health. Springer, Dordrecht, 2014. 43-68. https://doi.org/10.1007/978-94-007-5640-3_4

Schmidt, S. W. (2007). The relationship between satisfaction with workplace training and overall job satisfaction. Human Resource Development Quarterly, 18(4), 481-498. https://doi.org/10.1002/hrdq.1216

Schmitt, M. T., Branscombe, N. R., Kobrynowicz, D., \& Owen, S. (2002). Perceiving discrimination against one's gender group has different implications for well-being in women and men. Personality and Social Psychology Bulletin, 28(2), 197-210. https://doi.org/10.1177/0146167202282006

Schope, R. D. (2002). The decision to tell: Factors influencing the disclosure of sexual orientation by gay men. Journal of Gay and Lesbian Social Services, 14(1), 1-22. https://doi.org/10.1300/J041v14n01_01

Schwepker Jr., C. H. (2001). Ethical climate's relationship to job satisfaction, organizational commitment and turnover intention in the sales force. Journal of Business Research, 54(1), 39-52. https://doi.org/10.1016/S0148-2963(00)00125-9

Sears, B., \& Mallory, C. (2011). Documented Evidence of Employment Discrimination and Its Impact on LGBT People. Los Angeles, CA: The Williams Institute.

Shapiro, J. P., Burkey, W. M., Dorman, R. L., \& Welker, C. J. (1996). Job satisfaction and burnout in child abuse professionals: Measure development, factor analysis, and job characteristics. Journal of Child Sexual Abuse, 5, 21-38. https://doi.org/10.1300/J070v05n03_02

Silla, I., \& Gamero, N. (2014). Shared time pressure at work and its health-related outcomes: Job satisfaction as a mediator. European Journal of Work and Organizational Psychology, 23(3), 405-418.

https://doi.org/10.1080/1359432X.2012.752898

Snape, E., \& Redman, T. (2010). HRM practices, organizational citizenship behaviour, and performance: A multi-level analysis. Journal of Management Studies, 47, 1219-1247. https://doi.org/10.1111/j.1467-6486.2009.00911.x

Stewart, G. L., \& Barrick, M. R. (2000). Team structure and performance: Assessing the mediating role of intrateam process and the moderating role of task type. Academy of management Journal, 43(2), 135-148. https://doi.org/10.5465/1556372

Stone, D. L., \& Colella, A. (1996). A model of factors affecting the treatment of disabled individuals in organizations. Academy of management review, 21(2), 352-401. https://doi.org/10.5465/amr.1996.9605060216

Storey, K., \& Garff, J. T. (1997). The cumulative effect of natural support strategies and social skills instruction on the integration of a worker in supported employment. Journal of Vocational Rehabilitation, 9(2), 143-152. https://doi.org/10.3233/JVR-1997-9207

Tajfel, H., Turner, J. C., Austin, W. G., \& Worchel, S. (1979). An integrative theory of intergroup 
conflict. Organizational identity: A reader, 56-65.

Taylor, P., Mcloughlin, C., Meyer, D., \& Brooke, E. (2013). Everyday discrimination in the workplace, job satisfaction and psychological wellbeing: Age differences and moderating variables. Ageing and Society, 33(7), 1105-1138. https://doi.org/10.1017/S0144686X12000438

Uppal, S. (2005). Disability, workplace characteristics and job satisfaction. International Journal of Manpower, 26(4), 336-349. https://doi.org/10.1108/01437720510609537

Verkuyten, M. (2016). The integration paradox: Empiric evidence from the Netherlands. American Behavioral Scientist, 60(5-6), 583-596. https://doi.org/10.1177/0002764216632838

Wallace, J. E. (1995). Organizational and professional commitment in professional and nonprofessional organizations. Administrative Science Quarterly, 228-255. https://doi.org/10.2307/2393637

Zacharatos, A., Barling, J., \& Iverson, R. D. (2005). High-performance work systems and occupational safety. Journal of applied psychology, 90(1), 77. https://doi.org/10.1037/0021-9010.90.1.77

Zeytinoglu, I. et al. (2007). Associations between work intensification, stress and job satisfaction: The case of nurses in Ontario. Relations Industrielles/Industrial Relations, 62(2), 201-225.

https://doi.org/10.7202/016086ar 


\section{Appendix}

Table 1. List of variables (and their meaning) used in this study's models

\begin{tabular}{|c|c|c|}
\hline & Variables & Type and Meaning \\
\hline \multirow{8}{*}{ 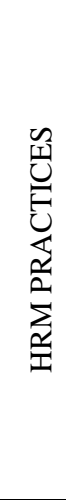 } & Autonomy & Dichotomous Variable $=1$ if respondent is endowed with autonomy \\
\hline & Team endowed with discretion & $\begin{array}{l}\text { Dichotomous Variable }=1 \text { if respondent work in a team endowed with } \\
\text { discretion }\end{array}$ \\
\hline & Colleagues support & Dichotomous Variable $=1$ if respondent is supported by colleagues \\
\hline & Boss support & Dichotomous Variable $=1$ if respondent is supported by superiors \\
\hline & Intensity & Dichotomous Variable $=1$ if respondent works with intensity \\
\hline & Discretion & Dichotomous Variable $=1$ if respondent is endowed with discretion \\
\hline & Performance Pay & Dichotomous Variable $=1$ if respondent is receive performance-related pay \\
\hline & Training & Dichotomous Variable $=1$ if respondent is trained at work \\
\hline \multirow{11}{*}{ 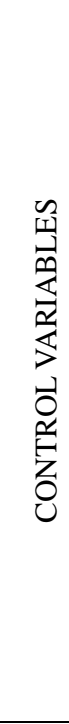 } & Trust the management & Dichotomous Variable $=1$ if respondent trusts in management \\
\hline & Female & Dichotomous Variable $=1$ if respondent is female \\
\hline & Employee & Dichotomous Variable $=1$ if respondent is employed and not self-employed \\
\hline & High education & Dichotomous Variable $=1$ if respondent is a graduate \\
\hline & Private sector & Dichotomous Variable $=1$ if respondent works in private sector \\
\hline & Rule of law countries & $\begin{array}{l}\text { Dichotomous Variable }=1 \text { if respondent works in one of the five countries in } \\
\text { which the rule of law is better experienced (WJP Rule of Law Index 2015) }\end{array}$ \\
\hline & Open-ended contract & Dichotomous Variable $=1$ if respondent have a permanent contract \\
\hline & Part-time & Dichotomous Variable $=1$ if respondent works part-time \\
\hline & Urban & $\begin{array}{l}\text { Dichotomous Variable }=1 \text { if respondent works in a city or in a semi-urban } \\
\text { region, and not in a rural region. }\end{array}$ \\
\hline & Age & Continuous Variable \\
\hline & AgeSQ & Continuous Variable $=$ Age $*$ Age \\
\hline \multirow{7}{*}{ 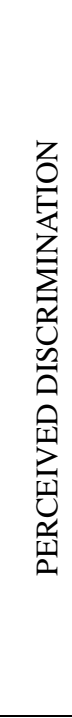 } & Discrimination & Dichotomous Variable $=1$ if respondent perceived to be discriminated against \\
\hline & Sexual orientation discrimination & $\begin{array}{l}\text { Dichotomous Variable }=1 \text { if respondent perceived to be discriminated against } \\
\text { on the ground of sexual orientation }\end{array}$ \\
\hline & Age discrimination & $\begin{array}{l}\text { Dichotomous Variable }=1 \text { if respondent perceived to be discriminated against } \\
\text { on the ground of age }\end{array}$ \\
\hline & Disability discrimination & $\begin{array}{l}\text { Dichotomous Variable }=1 \text { if respondent perceived to be discriminated against } \\
\text { on the ground of disability }\end{array}$ \\
\hline & Gender discrimination & $\begin{array}{l}\text { Dichotomous Variable }=1 \text { if respondent perceived to be discriminated against } \\
\text { on the ground of gender }\end{array}$ \\
\hline & Ethnicity discrimination & $\begin{array}{l}\text { Dichotomous Variable = } 1 \text { if respondent perceived to be discriminated against } \\
\text { on the ground of ethnicity }\end{array}$ \\
\hline & $\begin{array}{l}\text { Intersectionality with Sex. Or. } \\
\text { discrimination }\end{array}$ & $\begin{array}{l}\text { Dichotomous Variable }=1 \text { if respondent perceived to be discriminated against } \\
\text { on the ground of sexual orientation and at last another characteristic. }\end{array}$ \\
\hline H & Job Satisfaction & Dichotomous Variable $=1$ if respondent is satisfied with their job \\
\hline
\end{tabular}

Source: our elaboration of EWCS 2015 sample. 
Table 2. Correlation Matrix of job satisfaction and some specific autonomy-oriented HRM practices.

\begin{tabular}{|c|c|c|c|c|c|c|}
\hline & Job Sat & [Q53f] & [Q61c] & [Q61d] & [Q61e] & [Q61i] \\
\hline Job Sat & 1.000 & & & & & \\
\hline [Q53f] & 0.1016 & 1.0000 & & & & \\
\hline [Q61c] & 0.2212 & 0.1955 & 1.0000 & & & \\
\hline [Q61d] & 0.1765 & 0.2495 & 0.4239 & 1.0000 & & \\
\hline [Q61e] & 0.1590 & 0.1551 & 0.3615 & 0.4145 & 1.0000 & \\
\hline [Q61i] & 0.1198 & 0.2483 & 0.2499 & 0.4024 & 0.2737 & 1.0000 \\
\hline
\end{tabular}

Source: our elaboration of EWCS 2015 sample.

Table 3. Correlation Matrix of job satisfaction and some specific discretion-oriented HRM practices

\begin{tabular}{|c|c|c|c|c|c|c|}
\hline & Job Sat & [Q53b] & [Q53e] & [Q53c] & [Q54a] & [Q54b] \\
\hline Job Sat & 1.000 & & & & & \\
\hline [Q53b] & 0.0530 & 1.0000 & & & & \\
\hline [Q53c] & 0.0402 & 0.4415 & 1.0000 & & & \\
\hline [Q53c] & 0.0719 & 0.3581 & 0.4233 & 1.0000 & & \\
\hline [Q54a] & -0.0345 & 0.2495 & 0.3214 & 0.2697 & 1.0000 & \\
\hline [Q54b] & -0.0393 & 0.2573 & 0.3489 & 0.2788 & 0.5773 & 1.0000 \\
\hline
\end{tabular}

Source: our elaboration of EWCS 2015 sample.

\section{Copyrights}

Copyright for this article is retained by the author(s), with first publication rights granted to the journal.

This is an open-access article distributed under the terms and conditions of the Creative Commons Attribution license (http://creativecommons.org/licenses/by/4.0/). 